\title{
p53 Family: Role of Protein Isoforms in Human Cancer
}

\author{
Jinxiong Wei, Elena Zaika, and Alexander Zaika \\ Department of Surgery and Cancer Biology, Vanderbilt University Medical Center, 1255 Light Hall, 2215 Garland Avenue, \\ Nashville, TN 37232, USA \\ Correspondence should be addressed to Alexander Zaika, alex.zaika@vanderbilt.edu
}

Received 29 April 2011; Accepted 4 July 2011

Academic Editor: Didier Auboeuf

Copyright (C) 2012 Jinxiong Wei et al. This is an open access article distributed under the Creative Commons Attribution License, which permits unrestricted use, distribution, and reproduction in any medium, provided the original work is properly cited.

TP53, TP63, and TP73 genes comprise the p53 family. Each gene produces protein isoforms through multiple mechanisms including extensive alternative mRNA splicing. Accumulating evidence shows that these isoforms play a critical role in the regulation of many biological processes in normal cells. Their abnormal expression contributes to tumorigenesis and has a profound effect on tumor response to curative therapy. This paper is an overview of isoform diversity in the p53 family and its role in cancer.

\section{Introduction}

Alternative splicing allows a single gene to express multiple protein variants. It is estimated that $92-95 \%$ of human multiexon genes undergo alternative splicing $[1,2]$. Abnormal alterations of splicing may interfere with normal cellular homeostasis and lead to cancer development [3-5].

The p53 protein family is comprised of three transcription factors: $\mathrm{p} 53, \mathrm{p} 63$, and p73. Phylogenetic analysis revealed that this family originated from a p63/73-like ancestral gene early in metazoan evolution [6,7]. Maintenance of genetic stability of germ cells seems to be its ancestral function [8]. The p53 family regulates many vital biological processes, including cell differentiation, proliferation, and cell death/apoptosis $[9,10]$. Dysregulation of the p53 family plays a critical role in tumorigenesis and significantly affects tumor response to therapy. This review summarizes current data on the regulation of $\mathrm{p} 53, \mathrm{p} 63$, and $\mathrm{p} 73$ isoforms and their roles in cancer.

\section{Structure and Function}

p53, p63, and p73 genes are located on chromosomes $17 \mathrm{p} 13.1,3 \mathrm{q} 27-29$, and $1 \mathrm{p} 36.2-3$, respectively. These genes encode proteins with similar domain structures and significant amino acid sequence homology in the transactivation, DNA-binding and oligomerization domains (Figure 1). The highest amino acid identity is in the DNA-binding domain
( $60 \%)$. Evolutionally, this domain is the most conserved, suggesting that regulation of transcription plays a pivotal role in an array of functions attributed to the p53 family. Less similarity is found in the oligomerization and transactivation domains $(\sim 30 \%)$.

The founding member of the $\mathrm{p} 53$ family, the $\mathrm{p} 53$ protein, had been discovered more than three decades ago $[12,13]$. For a long time, it had been assumed that p53 is expressed as a single polypeptide. However, when it had been found that the p63 and p73 genes encoded a large variety of diverse transcripts, the p53 gene transcription was revisited. Now we know that $\mathrm{p} 53$ forms multiple variants.

Transcriptions of $\mathrm{p} 53, \mathrm{p} 63$, and $\mathrm{p} 73$ genes are regulated by similar mechanisms. It is controlled by two promoters: $\mathrm{P} 1$ and $\mathrm{P} 2$, where $\mathrm{P} 2$ is an alternative intragenic promoter (Figure 1). One study in silico provided evidence for the existence of a third putative promoter in the first intron of human TP73 gene [14]. Therefore, it would not be surprising if additional gene promoters will be found in the future. An extensive alternative splicing adds further diversity to the promoters' products. The produced transcripts and proteins can be generally categorized into two main groups, termed TA and $\Delta \mathrm{N}[15,16]$. TA variants contain the $\mathrm{N}$ terminal transactivation domain while $\Delta \mathrm{N}$ isoforms lack the entire (or part of) domain. It was initially thought that $\Delta \mathrm{N}$ isoforms are only generated by the $\mathrm{P} 2$ promoter whereas the P1 promoter regulates TA isoforms. Further analysis of alternative mRNA splicing revealed that some 
(A)

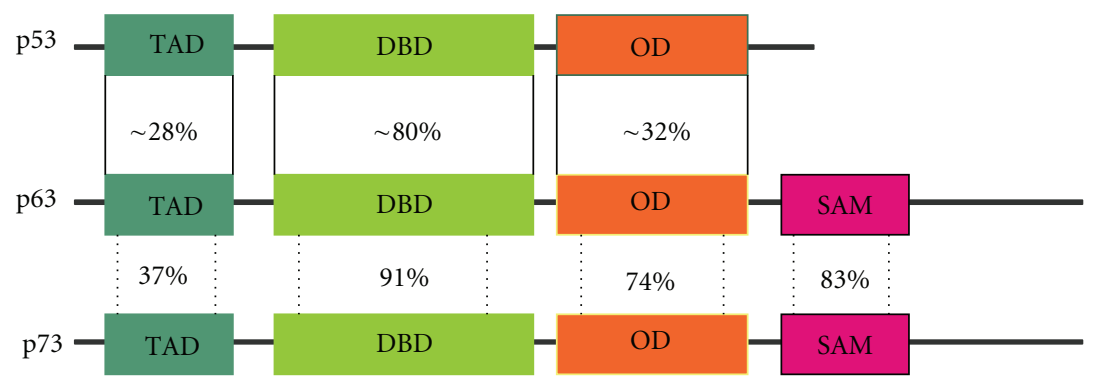

(B)
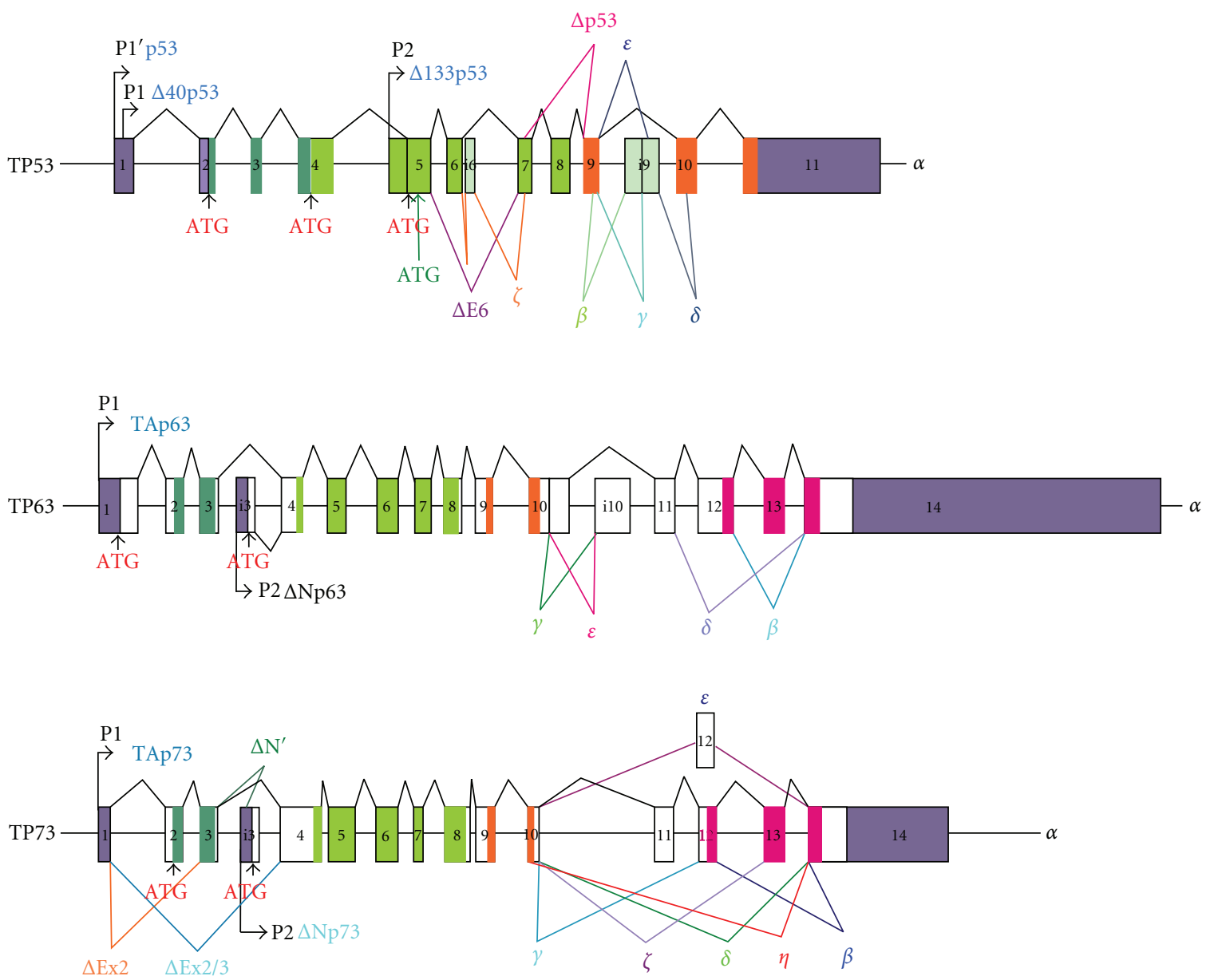

Figure 1: Architectures of human TP53, TP73, and TP63 genes. (A) TP53, TP73, and TP63 genes encode the transactivation (TAD), DNAbinding (DBD), and oligomerization (OD) domains. TP73 and TP63 encode additional SAM (Sterile Alpha Motif) domain. Percentage homology of residues between p53, p63, and p73 is shown [11]. (B) TP53, TP63, and TP73 genes have two promoters (P1 and P2). The P1 promoters produce transactivation-competent full-length proteins (TA) while the $\mathrm{P} 2$ promoters produce TAD-deficient proteins $(\triangle \mathrm{N})$ with dominant-negative functions. p53 gene transcription is initiated from two distinct sites (P1 and $\left.\mathrm{P} 1^{\prime}\right)$.

transcriptionally deficient isoforms are products of the P1 promoter. For example, the P1 promoter of the TP73 gene regulates TAp73 isoforms and isoforms, which lack the TA domain: $\Delta \operatorname{Ex} 2 \mathrm{p} 73, \Delta \mathrm{Ex} 2 / 3 \mathrm{p} 73$, and $\Delta \mathrm{N}^{\prime} \mathrm{p} 73$. The latter isoforms are missing either exon $2(\Delta \mathrm{Ex} 2 \mathrm{p} 73)$ or both exon 2 and $3(\Delta \mathrm{Ex} 2 / 3 \mathrm{p} 73)$ or contain an additional exon $3^{\prime}$ $\left(\Delta \mathrm{N}^{\prime} \mathrm{p} 73\right)[17,18]$. Other $\Delta \mathrm{Np} 73$ transcripts are products of the P2 promoter. Similar to p73, the P1 promoter of the p53 gene produces transcriptionally active isoforms [5].
The alternative splicing is responsible for transcriptionally deficient isoforms of $\Delta 40 \mathrm{p} 53$, which missing the first 40 amino acids at the $\mathrm{N}$-terminus $[5,19,20]$. Additional p53 transcriptionally deficient isoforms $(\Delta 133 \mathrm{p} 53$ and $\Delta 160 \mathrm{p} 53)$ are regulated by the $\mathrm{P} 2$ promoter located in intron 4 of the p53 gene $[5,21]$.

Additional diversity of p53, p63, and p73 transcripts is generated by alternative splicing at the $3^{\prime}$ end of the transcripts (Figure 1). These splice variants are traditionally 


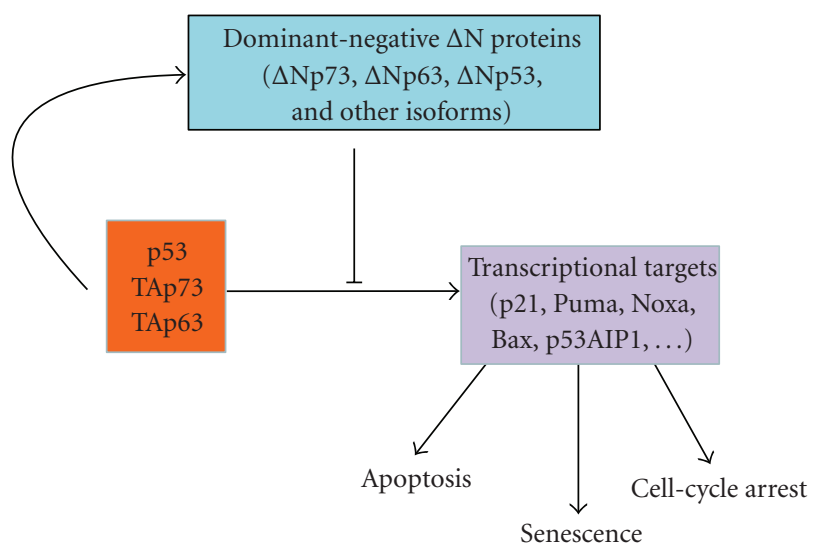

FIGURE 2: Interactions of p53 family isoforms. N-terminally truncated isoforms of p53, p73, and p63 play a dominant-negative role inhibiting transcriptional and other biological activities of TA isoforms.

named with letters of the Greek alphabet. Initially, three such splice variants have been described for $\mathrm{p} 63$ and $\mathrm{p} 53(\alpha, \beta$, $\gamma)$, and nine for $\mathrm{p} 73(\alpha, \beta, \gamma, \delta, \varepsilon, \theta, \zeta, \eta$, and $\eta 1)$ [22-25]. Later, additional p63 splice variants $(\delta, \varepsilon)$ and $\mathrm{p} 53(\delta, \varepsilon, \zeta$, $\Delta \mathrm{E} 6)$ were reported [26-28]. However, it should be noted that a majority of $\mathrm{p} 53, \mathrm{p} 63$, and $\mathrm{p} 73$ studies focus on a few isoforms, primarily $\alpha, \beta$, and $\gamma$. Little is known about the functions of other isoforms. The combination of alternative splicing at the $5^{\prime}$ and $3^{\prime}$ ends, alternative initiation of translation and alternative promoter usage can significantly increase protein diversity. For example, $\mathrm{N}$-terminal variants (p53, $\Delta 40 \mathrm{p} 53, \Delta 133 \mathrm{p} 53$, and $\Delta 160 \mathrm{p} 53)$ can be produced in $\alpha, \beta$, and $\gamma$ "flavors" $[20,21]$. Theoretically, the p53 gene can produce at least 20 isoforms, p63 at least 10 , and p73 more than 40 , though not all have been experimentally confirmed.

p53, TAp63, and TAp73 share significant functional resemblance. They can induce cell cycle arrest, apoptosis, or cellular senescence. This similarity can be explained, at least in part, by transactivation of the same transcriptional targets. Genome-wide analyses found an overlap of the transcription profiles of p53, TAp73, and TAp63, though unique targets were identified as well. Analyses using chromatin immunoprecipitation, reporter, and gel-shift assays found that TAp73 and TAp63 interact with p53-responsive elements.

The transactivation and apoptotic potential of $\mathrm{p} 53$, TAp73, and TAp63 vary greatly depending on the isoform. TAp63 $\gamma$ and TAp73 $\beta$ are similar to that of $\mathrm{p} 53 \alpha$ [29]. Other isoforms are considered less active on the p53 target gene promoters $[9,23,30]$. Some isoforms are characterized by a variation in domain structure. TAp73 $\alpha$ and TAp63 $\alpha$ have an additional domain at the $\mathrm{COOH}$-terminus that is not found in p53. This domain, termed SAM or Sterile Alpha Motif, is responsible for protein-protein interactions and is found in a diverse range of proteins that are involved in developmental regulation. It is also implicated in transcriptional repression [31]. Beta and gamma isoforms of p53 are missing most of the oligomerization domain that results in decreased transcriptional activity $[5,32,33]$.

$\Delta \mathrm{N}$ isoforms function as dominant-negative inhibitors of TA counterparts (Figure 2). Promoter competition and heterocomplex formation have been suggested to explain this phenomenon $[17,34,35]$. In the promoter competition mechanism, the suggestion is that $\Delta \mathrm{N}$ competes off TA isoforms from their target gene promoters, thus preventing efficient transcription. In the heterocomplex formation mechanism, $\Delta \mathrm{N}$ isoforms would inhibit TA by forming hetero-oligomeric complexes.

$\Delta \mathrm{N}$ isoforms of $\mathrm{p} 53$ and $\mathrm{p} 73$ are regulated by a negative feedback loop mechanism. Analogous mechanism was not described for p63 despite its significant similarity to p73. In a nutshell, TA isoforms are able to induce transcription of $\Delta \mathrm{N}$ isoforms by activating $\mathrm{P} 2$ promoters. The induced $\Delta \mathrm{N}$ isoforms, in turn, inhibit TA isoforms. A good example of these interactions is an induction of $\Delta 133 \mathrm{p} 53$ by p $53[5,36-$ 38]. Similarly, TAp73 and $\mathrm{p} 53$ are important regulators of transcriptions of $\Delta N p 73$ [39]. It appears that the balance between $\Delta \mathrm{N}$ and $\mathrm{TA}$ isoforms is finely tuned to regulate the activities of TA isoforms. The net effect of these interactions in a given context appears to be dependent on the TA/ $\Delta \mathrm{N}$ expression ratio. Deregulation of this mechanism may lead to tumor development [40-42]. However, it has become clear that the role of $\Delta \mathrm{N}$ isoforms is multifaceted. The dominant negative concept cannot explain the complexity of all the interactions attributed to $\Delta \mathrm{N}$ isoforms. Several studies reported that $\Delta \mathrm{N}$ isoforms can retain transcription activity through additional transactivation domains.

\section{Role of p53 Isoforms in Cancer}

Although many aspects of p53 biology have been thoroughly investigated, the role and regulation of p53 isoforms remain not well understood.

Recent studies suggested that $\Delta 133 \mathrm{p} 53$ isoform may play an oncogenic role. Mice overexpressing the $\Delta 122 \mathrm{p} 53$ isoform (murine homolog of human $\Delta 133 \mathrm{p} 53$ ) show reduced apoptosis, increased cell proliferation and develop a wide-spectrum of aggressive tumors including lymphoma, osteosarcoma, and other malignant and benign tumors [43]. Another phenotypic characteristic of these mice is elevated 
cytokine levels in the blood and widespread inflammation in many organs. Interestingly, transgenic expression of another p53 isoform, $\Delta 40 \mathrm{p} 53$, does not lead to tumor formation in mice, but is associated with a short life span, cognitive decline, and overt diabetes, suggesting a significant difference between these isoforms [44-46].

Several studies reported an elevated expression of $\Delta 133$ p53 in tumors (Table 1). In breast tumors, 24 of 30 cases showed an increased expression of $\Delta 133 \mathrm{p} 53$, but low or undetectable levels in normal breast tissue [5]. An increase of $\Delta 133 \mathrm{p} 53 \alpha \mathrm{mRNA}$ was also found in renal cell carcinoma [47]. In colon tumors, progression from colon adenoma to carcinoma is accompanied by an increase of $\Delta 133 \mathrm{p} 53$ mRNA. This study suggested that $\Delta 133$ p53 helps to escape from the senescence barrier during colon tumor progression [48]. Interestingly, the $\Delta 133$ p53 expression level is associated with the mutation status of p53; colon tumors expressing wildtype p53 had higher levels of $\Delta 133$ p53 than p53 mutant tumors [48]. In addition to $\Delta 133 \mathrm{p} 53$, an increased expression of $\Delta 40 \mathrm{p} 53$ was also reported in human melanoma cell lines and primary melanoma isolates [33]. However, not all tumors overexpress $\Delta 133 \mathrm{p} 53$. Analysis of squamous carcinoma of the head and neck did not reveal any significant changes in the $\Delta 133$ p53 levels, suggesting that this isoform may only play a tumor-promoting role in a subset of tissues [49].

Alterations of $\mathrm{p} 53 \beta$ and $\mathrm{p} 53 \gamma$ isoforms were also reported in different types of cancers (Table 1). An increased expression of $\mathrm{p} 53 \beta$ was found in renal cell carcinoma and in most melanoma cell lines. In renal cell carcinoma, p53 $\beta$ expression was associated with tumor progression [47]. p53 $\beta$ was also found to correlate with worse recurrencefree survival in ovarian cancer patients with functionally active p53 [28]. Decreased p53 $\beta$ and p53 $\gamma$ mRNA levels were reported in breast cancer [5]. In breast tumors, p53 $\beta$ is associated with the expression of estrogen receptor but not with disease outcome [50]. Breast cancer patients expressing both mutant p53 and p53 $\gamma$ have lower cancer recurrence and favorable prognosis [51]. Currently, specific functions of $\mathrm{p} 53 \beta$ and $\mathrm{p} 53 \gamma$ remain unclear. A significant hurdle to the studies of p53 isoforms in tumors is the lack of isoformspecific antibodies. The generation of new antibodies, animal models, and additional tumor studies may help to better understand the role of p53 isoforms in tumorigenesis.

\section{Role of p73 Isoforms in Cancer}

The role of p73 in tumorigenesis is still a matter of debate. In contrast to p53, p73 is rarely mutated and frequently overexpressed in human tumors [23, 52-56]. An initial study of p73-deficient mice found a number of developmental defects and no spontaneous tumors [57]. Follow-up studies have revealed spontaneous tumorigenesis, although the late onset of tumors and smaller tumor sizes compared to p53-deficient animals were reported. The basis for these conflicting results in cancer susceptibility remains obscure but might be related to the animal genetic background and housing conditions. Mice with isoform-specific knockouts of p73 have also been generated; phenotypes of these animals generally reflect previously reported differences between p73 isoforms. TAp73 null mice are tumor prone while $\Delta \mathrm{Np} 73$ knockouts have increased sensitivity to DNA-damaging agents and elevated p53-dependent apoptosis [58, 59].

Several studies have found that N-terminally truncated isoforms of p73 play an oncogenic role and are linked to cancer development (Table 1). Targeted transgenic overexpression of human $\Delta \mathrm{Ex} 2 / 3 \mathrm{p} 73$ in the mouse liver resulted in the development of hepatocellular carcinoma [60]. The $\mathrm{N}$-terminally truncated isoforms are upregulated in many human cancers including liver, ovarian, breast, vulvar cancers, and melanoma $[23,61-68]$. Overexpression of $\Delta \mathrm{Ex} 2 \mathrm{p} 73$ and $\Delta \mathrm{Ex} 2 / 3 \mathrm{p} 73$ was found to be associated with metastases in melanoma [68].

$\Delta \mathrm{Np} 73$, which is produced by the $\mathrm{P} 2$ promoter, has also been found to behave as an oncogene. $\Delta \mathrm{Np} 73$ facilitates immortalization of primary mouse embryonic fibroblasts and cooperates with oncogenic Ras in their transformation. These transformed cells produce tumors following a subcutaneous injection into nude mice $[121,122] . \Delta \mathrm{Np} 73$ also inhibits differentiation of myoblasts and protects them against apoptosis [123]. Studies by others and us found that $\triangle \mathrm{Np} 73$ is upregulated in a number of tumors and is associated with metastases, chemotherapeutic failure, and poorer patient prognosis $[62,74,96,124-130]$.

An important question is what causes deregulation of p73 isoforms in tumors? One of the mechanisms is tumorspecific alternative mRNA splicing. It has been demonstrated that the alternative splicing causes incorporation of a new exon 3' into TAp73 transcripts resulting in a translational switch from TAp73 to $\triangle \mathrm{Np} 73$ isoform $[18,61]$. An interesting observation was also made in hepatocellular carcinoma where an aberrant switch from TAp73 to $\Delta \mathrm{Ex} 2 \mathrm{p} 73$ was found to be mediated by the activation EGFR by amphiregulin. This leads to activation of JNK1 kinase, suppression of splicing factor Slu7, and alternative splicing of p73 transcripts [65]. Activated Ras has also been shown to decrease TAp73 levels and increase $\triangle \mathrm{Np} 73$ expression during cellular transformation [131]. Abnormal regulation of the P2 promoter has also been reported. We found that transcriptional repressor HIC1 (Hypermethylated In Cancer 1) can suppress expression of $\Delta \mathrm{Np} 73$ by inhibiting the $\mathrm{P} 2$ promoter in normal cells. Loss of HIC1 in esophagus and gastric cancer cells leads to upregulation of $\Delta \mathrm{Np} 73$ [96]. In a subset of tumors, abnormal epigenetic changes cause deregulation of p73 isoforms [132134]. Hypomethylation of the P2 promoter was found in more than half of non-small lung cancers [76].

An increased expression of TAp73 isoforms was also found in tumors, although its role remains unclear (Table 1). Several studies suggested that in specific circumstances TAp73 might play a tumor-promoting role [30, 135]. Interestingly, some tumors tend to increase a variety of p73 splice isoforms (Figure 3 ). In the normal colon and breast, p73 $\alpha$ and $\mathrm{p} 73 \beta$ isoforms are predominant whereas other spliced variants $(\gamma, \delta, \phi$, and $\varepsilon)$ are primarily detected in colon and breast cancers $[15,23]$. This phenomenon was also observed in acute myeloid leukemia. Moreover, the p $73 \varepsilon$ isoform was only expressed in leukemic cells and completely absent in 
TABLE 1: Summary of alterations of the p53 family members in human cancers.

\begin{tabular}{|c|c|c|c|}
\hline Protein & Cancer type & Number of cases & Ref. \\
\hline & Breast cancer & & \\
\hline \multirow[t]{6}{*}{ p53 } & $\begin{array}{l}\text { (i) p } 53 \beta \text { was detected in } 36 \% \text { breast tumors and associated with the } \\
\text { expression of estrogen receptor (ER). }\end{array}$ & \multirow{3}{*}{127 breast tumors } & \multirow{3}{*}[50]{} \\
\hline & $\begin{array}{l}\text { (ii) p53y was detected in } 37 \% \text { breast tumors and associated with } \\
\text { mutations in the p53 gene. }\end{array}$ & & \\
\hline & $\begin{array}{l}\text { (iii) Patients with mutant p } 53 \text { and p } 53 \gamma \text { isoform had a low cancer } \\
\text { recurrence and an overall survival as good as that of patients with wild } \\
\text { type p53. }\end{array}$ & & \\
\hline & $\begin{array}{l}\text { (i) } \mathrm{p} 53, \mathrm{p} 53 \beta \text {, and } \mathrm{p} 53 \gamma \mathrm{mRNA} \text {, but not transcripts for } \Delta 133 \mathrm{p} 53 \alpha \text {, } \\
\Delta 133 \mathrm{p} 53 \beta \mathrm{mRNA} \text {, and } \Delta 133 \mathrm{p} 53 \gamma \text {, were detected in normal breast } \\
\text { tissues. }\end{array}$ & \multirow{3}{*}{$\begin{array}{l}30 \text { breast tumors and } 8 \text { normal } \\
\text { breast samples }\end{array}$} & \multirow[t]{3}{*}[5]{} \\
\hline & $\begin{array}{l}\text { (ii) } \mathrm{p} 53 \beta \text { mRNA was detected in } 10 / 30 \text { tumors; } \Delta 133 \mathrm{p} 53 \alpha \text { mRNA was } \\
\text { detected in } 24 / 30 \text { tumors; } 53 \gamma, \Delta 133 \mathrm{p} 53 \beta \text {, and } \Delta 133 \mathrm{p} 53 \gamma \text { were } \\
\text { undetected in tumors. }\end{array}$ & & \\
\hline & (iii) Some tumors can express mutant p53 but wild type $\Delta 133 \mathrm{p} 53$. & & \\
\hline \multirow[t]{10}{*}{ p73 } & (i) $\triangle$ TAp73 and TAp73 mRNA were upregulated in tumors. & & \\
\hline & $\begin{array}{l}\text { (ii) Expression of } \Delta \operatorname{Ex} 2 \mathrm{p} 73(P=.05) \text { is associated with vascular } \\
\text { invasion; a trend was found between } \Delta \mathrm{Np} 73 \text { and vascular invasion } \\
(P=.06) \text {. }\end{array}$ & 60 breast cancers & {$[62]$} \\
\hline & $\begin{array}{l}\text { (iii) Increased expression of } \Delta \mathrm{Ex} 2 \mathrm{p} 73 \text { and } \Delta \mathrm{Ex} 2 / 3 \mathrm{p} 73 \text { were associated } \\
\text { with ER status }(P=.06 \text { and } P=.07) \text {; overexpression of TAp } 73 \text { was } \\
\text { associated with progesterone receptor expression }(P=.06) .\end{array}$ & & \\
\hline & $\begin{array}{l}\text { (i) Mutational analysis revealed five silent mutations in } 29 \text { hereditary } \\
\text { tumors; no p73 mutations were detected in } 48 \text { sporadic cancers. }\end{array}$ & $\begin{array}{l}29 \text { hereditary and } 48 \text { sporadic } \\
\text { breast cancers }\end{array}$ & {$[52]$} \\
\hline & $\begin{array}{l}\text { (i) Thirteen percent of informative cases showed LOH of the p } 73 \text { gene; } \\
\text { no correlation was found between the p } 73 \mathrm{LOH} \text { and clinical features. }\end{array}$ & \multirow{3}{*}{87 primary breast cancer specimens } & \multirow{3}{*}[69]{} \\
\hline & $\begin{array}{l}\text { (ii) No changes of p } 73 \text { transcript levels in breast cancers compared to } \\
\text { normal breast tissues. }\end{array}$ & & \\
\hline & $\begin{array}{l}\text { (iii) PCR-SSCP analysis did not detect any missense or frameshift } \\
\text { mutations in the p } 73 \text { gene. }\end{array}$ & & \\
\hline & $\begin{array}{l}\text { (i) Elevated expression of p } 73 \text { mRNA was found in } 29 / 77 \text { breast tumors; } \\
\text { no correlation of p } 73 \text { expression with the p53 status. }\end{array}$ & \multirow{3}{*}{77 invasive breast cancers } & \multirow{3}{*}[23]{} \\
\hline & (ii) New p73 isoforms were identified. & & \\
\hline & (iii) No coding mutations were found in all coding exons. & & \\
\hline \multirow[t]{4}{*}{ p63 } & (i) p63 protein was strongly expressed in $13 / 15$ metaplastic carcinomas. & & \\
\hline & $\begin{array}{l}\text { (ii) All metaplastic carcinomas with spindle cells and/or squamous } \\
\text { differentiation were positive for p63. One tumor out of } 174 \\
\text { nonmetaplastic invasive carcinomas expressed p63. }\end{array}$ & 189 invasive breast carcinomas & {$[70]$} \\
\hline & $\begin{array}{l}\text { (i) p63 protein expression was correlated with EBNA-1 } \\
\text { immunostaining, suggesting a potential involvement of p63 in } \\
\text { mammary tumorigenesis associated with Epstein-Barr virus infection. }\end{array}$ & 85 breast carcinomas & {$[71]$} \\
\hline & $\begin{array}{l}\text { (i) Survival analysis revealed a better prognosis for ER-positive patients } \\
\text { with p63 mRNA expression; no other correlations were found. }\end{array}$ & $\begin{array}{l}2,158 \text { ER positive breast cancers and } \\
140 \text { normal breast biopsies. }\end{array}$ & {$[72]$} \\
\hline
\end{tabular}


TABle 1: Continued.

\begin{tabular}{|c|c|c|c|}
\hline \multirow[t]{2}{*}{ Protein } & Cancer type & Number of cases & Ref. \\
\hline & \multicolumn{2}{|l|}{ Lung cancer } & \\
\hline \multirow[t]{13}{*}{ p73 } & $\begin{array}{l}\text { (i) p73 mRNA expression was increased in } 87 \%(52 / 60) \text { tumors } \\
\text { compared to normal lung tissues; no correlation with the p53 status was } \\
\text { found. }\end{array}$ & \multirow[t]{3}{*}{60 lung cancers } & \multirow[t]{3}{*}{ [73] } \\
\hline & (ii) No p73 gene amplification was detected. & & \\
\hline & (iii) p73 expression correlated with cancer histology and patient age. & & \\
\hline & $\begin{array}{l}\text { (i) } \Delta \mathrm{Np} 73 \text { expression was detected in the cytoplasm of tumor cells in } \\
77 / 132 \text { patients with lung cancer. No expression was found in the } \\
\text { surrounding normal stromal cells. The expression of } \Delta \mathrm{Np} 73 \text { was } 52.2 \% \text {, } \\
50.0 \% \text {, and } 70.2 \% \text { in stage I, II, and III tumor patients, respectively. }\end{array}$ & \multirow[t]{2}{*}{132 lung cancers } & \multirow[t]{2}{*}{ [74] } \\
\hline & $\begin{array}{l}\text { (ii) } \Delta \mathrm{Np} 73 \text { expression was a significant independent factor for } \\
\text { predicting poor prognosis. }\end{array}$ & & \\
\hline & (i) $\Delta \mathrm{Np} 73$ protein had primarily nuclear expression in $35 / 40$ cases. & \multirow{4}{*}{41 NSCLCs } & \multirow{4}{*}{ [75] } \\
\hline & (ii) TAp73 protein was found in the cytoplasm in $28 / 40$ cases. & & \\
\hline & (iii) $\Delta$ Np73 expression significantly correlated with p53 expression. & & \\
\hline & $\begin{array}{l}\text { (iv) No methylation of the } \mathrm{P} 1 \text { promoter was found; } \mathrm{P} 2 \text { promoter was } \\
\text { methylated in } 17 / 41 \text { tumors and partially or totally unmethylated in } \\
\text { 24/41 cases. }\end{array}$ & & \\
\hline & $\begin{array}{l}\text { (i) Hypermethylation of the } \mathrm{P} 1 \text { promoter of the } \mathrm{p} 73 \text { gene was relatively } \\
\text { uncommon. }\end{array}$ & \multirow[b]{2}{*}{102 NSCLCs } & \multirow[b]{2}{*}{ [76] } \\
\hline & $\begin{array}{l}\text { (ii) Hypomethylation of the } \mathrm{P} 2 \text { promoter was frequently found in } \\
\text { squamous cell carcinomas. }\end{array}$ & & \\
\hline & $\begin{array}{l}\text { (i) Expression of } \Delta E x 2 p 73 \text { and } \Delta E x 2 / 3 p 73 \text { was increased; expression of } \\
\Delta N p 73 \text { and } \Delta N \text { N'p } 73 \text { was decreased. }\end{array}$ & & \\
\hline & $\begin{array}{l}\text { (ii) Expression of p73 isoforms correlated with clinicopathological } \\
\text { variables. }\end{array}$ & 46 NSCLCs & [42] \\
\hline \multirow[t]{9}{*}{ p63 } & $\begin{array}{l}\text { (i) p63 protein expression was detected in } 109 / 118 \text { squamous cell } \\
\text { carcinomas, } 15 / 95 \text { adenocarcinomas, } 2 / 2 \text { adenosquamous carcinomas, } \\
4 / 6 \text { large cell carcinomas, } 9 / 20 \text { poorly differentiated neuroendocrine } \\
\text { tumors, and } 1 / 37 \text { typical and atypical carcinoids. }\end{array}$ & \multirow{3}{*}{$\begin{array}{l}221 \text { NSCLCs, } 57 \text { stage I-IV } \\
\text { neuroendocrine tumors }\end{array}$} & \multirow{3}{*}{ [77] } \\
\hline & $\begin{array}{l}\text { (ii) p63 expression was progressively increased from preneoplastic and } \\
\text { preinvasive lesions to invasive squamous cell carcinomas. }\end{array}$ & & \\
\hline & $\begin{array}{l}\text { (iii) p63 immunoreactivity was correlated with the KI- } 67 \text { labeling index } \\
\text { and inversely correlated with the tumor grade in squamous cell } \\
\text { carcinomas. }\end{array}$ & & \\
\hline & $\begin{array}{l}\text { (i) p63 genomic sequence was amplified in } 88 \% \text { of squamous } \\
\text { carcinomas, in } 42 \% \text { of large cell carcinomas, and in } 11 \% \text { of } \\
\text { adenocarcinomas of the lung. Genomic amplification of p63 is an early } \\
\text { event in the development of squamous carcinoma. }\end{array}$ & \multirow[t]{3}{*}{217 NSCLCs } & \multirow[t]{3}{*}{ [78] } \\
\hline & $\begin{array}{l}\text { (ii) } \Delta \mathrm{Np} 63 \alpha \text { was found to be the predominant } \mathrm{p} 63 \text { isoform in normal } \\
\text { bronchus and squamous carcinomas but not in normal lung or in } \\
\text { adenocarcinomas. }\end{array}$ & & \\
\hline & $\begin{array}{l}\text { (iii) p63 genomic amplification and protein staining intensity were } \\
\text { associated with better survival. }\end{array}$ & & \\
\hline & (i) p63 protein immunopositivity was found in $80 \%$ (48/60) NLCLCs. & \multirow{3}{*}{60 NSCLCs } & \multirow{3}{*}[79]{} \\
\hline & $\begin{array}{l}\text { (ii) Expression of p63 protein was associated with lymph node } \\
\text { metastasis and histological classification. }\end{array}$ & & \\
\hline & (iii) Expressions of p63 and p73 proteins were positively correlated. & & \\
\hline
\end{tabular}


TABle 1: Continued.

\begin{tabular}{|c|c|c|c|}
\hline Protein & Cancer type & Number of cases & Ref. \\
\hline & $\begin{array}{l}\text { (i) Nuclear } \Delta \text { Np63 staining was found in } 77 / 161 \text { specimens. } \\
\text { (ii) No significant correlation was observed between } \Delta N p 63 \text { expression } \\
\text { and clinicopathological variables. }\end{array}$ & 161 squamous cell carcinomas & {$[80]$} \\
\hline & $\begin{array}{l}\text { (i) Most of the p63 expression detected in nonneoplastic lung tissue was } \\
\text { localized to the nuclei of the bronchiolar basal cells. Nucleic and } \\
\text { cytoplasmic expression of p } 63 \text { protein was found in } 46 / 92(50 \%) \text { and } \\
47 / 92(51 \%) \text { cases. Nuclear localization of p63 was correlated with } \\
\text { nuclear accumulation of p53, but was not associated with patient } \\
\text { survival. } \\
\text { (ii) Cytoplasmic expression of p63 was found to be an adverse } \\
\text { prognostic factor in patients with lung adenocarcinoma. }\end{array}$ & 92 lung adenocarcinomas & {$[81]$} \\
\hline & $\begin{array}{l}\text { (i) } \triangle \text { Np63 isoform was upregulated }(P=.02) \text {, and TAp63 was slightly } \\
\text { downregulated }(P=.01) \text {. } \\
\text { (ii) TAp63 expression correlated with patient survival in non-squamous } \\
\text { tumors. }\end{array}$ & 46 NSCLCs & {$[42]$} \\
\hline & Prostate cancer & & \\
\hline p73 & $\begin{array}{l}\text { (i) No tumor-specific mutations were found in the p73 gene. } \\
\text { (ii) p73 was biallelically expressed in both normal prostate and tumor } \\
\text { tissues. } \\
\text { (iii) p73 mRNA expression was not altered in tumors compared to } \\
\text { normal prostate. }\end{array}$ & $\begin{array}{l}27 \text { prostate cancers and } 4 \text { prostate } \\
\text { cell lines }\end{array}$ & {$[82]$} \\
\hline & $\begin{array}{l}\text { (i) Significant increase of } \Delta \mathrm{Np} 73 \mathrm{mRNA} \text { was found in } 20 / 33(60 \%) \\
\text { prostate carcinomas and } 17 / 24(70 \%) \text { benign prostate hyperplasias. } \\
\Delta \mathrm{Np} 73 \mathrm{mRNA} \text { was not detected in the normal prostate. None of the } \\
\text { specimen expressed } \Delta \mathrm{N}^{\prime} \text { p } 73 \text {. } \\
\text { (ii) } \Delta \mathrm{Np} 73 \text { expression was significantly associated with the Gleason } \\
\text { score. No correlation was found between TAp73 expression and clinical } \\
\text { variables. }\end{array}$ & $\begin{array}{l}33 \text { prostate carcinomas, } 24 \text { benign } \\
\text { prostatic hyperplasia samples, and } \\
5 \text { normal samples }\end{array}$ & {$[83]$} \\
\hline p63 & $\begin{array}{l}\text { (i) p63 expression was reduced in prostate carcinomas compared to } \\
\text { matched normal tissues. } \\
\text { (ii) One tumor patient had a somatic mutation in exon 11, one prostate } \\
\text { cell line, CWR22Rv1, expressed mutant p63 ( } \mathrm{G} \text { to T substitution in exon } \\
\text { 8). }\end{array}$ & $\begin{array}{l}20 \text { tumors, } 20 \text { metastases, } 28 \\
\text { xenografts, and } 7 \text { prostate cancer } \\
\text { cell lines }\end{array}$ & {$[84]$} \\
\hline & $\begin{array}{l}\text { (i) Increased expression of cytoplasmic p63 proteins was associated with } \\
\text { increased cancer mortality. Cytoplasmic expression was also associated } \\
\text { with reduced levels of apoptosis and increased cellular proliferation. }\end{array}$ & 298 prostate cancers & {$[85]$} \\
\hline & Colon cancer & & \\
\hline p53 & $\begin{array}{l}\text { (i) Colon adenomas with senescence phenotype expressed elevated } \\
\text { levels of p } 53 \beta \text { and reduced levels of } \Delta 133 \text { p } 53 \text {. Colon carcinoma tissues } \\
\text { were characterized by increased } \Delta 133 \text { p } 53 \text { expression. Colon carcinomas } \\
\text { (stage I and II) had increased levels of p } 53 \beta \text { mRNA. }\end{array}$ & $\begin{array}{l}29 \text { colon carcinomas, } 8 \text { adenomas, } \\
\text { and } 9 \text { normal colon specimens }\end{array}$ & {$[48]$} \\
\hline p73 & $\begin{array}{l}\text { (i) p73 protein levels were significantly higher in primary colorectal } \\
\text { carcinomas. }\end{array}$ & & \\
\hline & $\begin{array}{l}\text { (ii) p73 and VEGF expression levels were correlated }(P=.016) \text {; p73 } \\
\text { positive colorectal adenocarcinoma showed significantly greater } \\
\text { vascularity. } \\
\text { (iii) There were no associations between p73 immunostaining and } \\
\text { tumor stage or differentiation. }\end{array}$ & $\begin{array}{l}56 \text { colon carcinomas with matched } \\
\text { normal specimens }\end{array}$ & {$[86]$} \\
\hline
\end{tabular}


Table 1: Continued.

\begin{tabular}{|c|c|c|c|}
\hline Protein & Cancer type & Number of cases & Ref. \\
\hline & $\begin{array}{l}\text { (i) TAp73 and } \Delta \text { TAp73 were significantly co-upregulated in colon } \\
\text { cancers. }\end{array}$ & \multirow{6}{*}{113 colon cancers } & \multirow{6}{*}[62]{} \\
\hline & $\begin{array}{l}\text { (ii) Expression of } \Delta \mathrm{Ex} 2 / 3 \mathrm{p} 73 \text { and } \Delta \mathrm{Np} 73 \text { isoforms was associated with } \\
\text { tumor stage }(P=.03 ; P=.011) .\end{array}$ & & \\
\hline & $\begin{array}{l}\text { (iii) } \Delta \mathrm{Np} 73 \text { overexpression was significantly associated with vascular } \\
\text { invasion }(P=.02) \text {. }\end{array}$ & & \\
\hline & $\begin{array}{l}\text { (iv) High levels of } \Delta \mathrm{Ex} 2 / 3 \mathrm{p} 73 \text { were associated with lymph node } \\
\text { metastases }(P=.04) .\end{array}$ & & \\
\hline & $\begin{array}{l}\text { (v) Up-regulation of TAp73 was associated with tumor localization } \\
(P=.004) .\end{array}$ & & \\
\hline & $\begin{array}{l}\text { (vi) Negative p53 staining correlated with overexpression of } \Delta \mathrm{Ex} 2 \mathrm{p} 73 \\
\text { and TAp73 }(P=.05 ; P=.05) .\end{array}$ & & \\
\hline \multirow[t]{2}{*}{ p63 } & $\begin{array}{l}\text { (i) p63 protein was primarily expressed in villous adenomas and poorly } \\
\text { differentiated adenocarcinomas. }\end{array}$ & \multirow{2}{*}{$\begin{array}{l}30 \text { colon adenomas, } \\
30 \text { adenocarcinomas }\end{array}$} & \multirow[t]{2}{*}[87]{} \\
\hline & (ii) p63 expression was not associated with p53. & & \\
\hline
\end{tabular}

Bladder cancer

p73 (i) p73 mRNA was increased in 18/45 bladder carcinomas and showed a strong correlation with tumor stage or grade; no allelic loss was found. High p73 expression was observed in 4/18 (22.2\%), 5/14 (35.7\%), and $9 / 13(69.2 \%)$ of grade I, II, and III tumors, respectively.

(ii) No p73 gene mutations were found by SSCP analysis.

(iii) No relationship between p73 and p53 mutations, expression of p21 and MDM2 was found.

(i) p73 mRNA was increased in 22/23 bladder cancers.

(ii) No tumor-specific mutations were found in coding exons of the p73 gene.

(iii) p73 was biallelically expressed in the normal bladder and cancer tissues.

23 primary invasive bladder cancers with matched normal tissues, 7 bladder cancer cell lines

(i) p73 protein was undetectable or low in 104/154 (68\%) transitional cell carcinomas of the bladder, primarily in invasive tumors.

(ii) Expression of p73 was associated with bladder cancer progression.

p63 (i) TAp63 was reduced in 25/47 (53.2\%) bladder carcinomas. The downregulation of TAp63 was associated with tumor stage and grade.

(ii) $\Delta$ Np63 was increased in 30/47 (63.8\%) tumors.

(iii) No mutations of p63 gene were found.

(iv) No association between p63 expression and the mutational status of p53 or expression of p21Waf1, MDM2, and 14-3-3 $\sigma$ in carcinomas was found.

(i) p63 immunostaining was decreased along tumor progression. Basal and intermediate cell layers of normal urothelium showed intense nuclear p63 staining. Lower p63 expression was significantly associated with TNM stage, lymph-node metastasis, and poor prognosis.

(i) $\Delta$ Np63 protein expression was increased in tumors and undetectable in normal bladder urothelium. $\Delta \mathrm{Np} 63$ expression was associated with an aggressive clinical course and poor prognosis. Patients with $\Delta$ Np63-negative tumors had a higher recurrence rate than those with $\Delta$ Np63-positive tumors.

(ii) $\mathrm{p} 63 \alpha$ expression was decreased in bladder carcinomas.
154 bladder transitional cell carcinomas

47 bladder carcinomas and 12 normal specimens

75 tumors

202 bladder carcinomas and 10 normal specimens 
Table 1: Continued.

\begin{tabular}{|c|c|c|c|}
\hline Protein & Cancer type & Number of cases & Ref. \\
\hline \multicolumn{4}{|c|}{ Melanoma } \\
\hline p53 & $\begin{array}{l}\text { (i) p53 } 3 \text { and } \Delta 40 \mathrm{p} 53 \text { mRNAs were expressed in the majority of } \\
\text { melanoma cell lines. These isoforms were absent or expressed at low } \\
\text { levels in fibroblasts and melanocytes. } \Delta 40 \mathrm{p} 53 \text { was found to inhibit } \\
\text { p53-dependent transcription whereas p } 53 \beta \text { enhances it. }\end{array}$ & 19 melanoma cell lines & {$[33]$} \\
\hline p73 & $\begin{array}{l}\text { (i) p73 mRNA expressed in the majority of human melanoma cell lines, } \\
\text { melanocytic nevi, primary malignant melanomas, and metastases. } \\
\text { (ii) No mutation was found in the DNA-binding domain of p73 in } 9 \\
\text { melanoma cell lines and } 5 \text { metastatic tumors. }\end{array}$ & $\begin{array}{l}9 \text { cell lines, } 17 \text { melanocytic nevi, } \\
17 \text { primary melanomas, and } 20 \\
\text { metastases }\end{array}$ & [93] \\
\hline & $\begin{array}{l}\text { (i) } \Delta \mathrm{Ex} 2 \mathrm{p} 73 \text { and } \Delta \mathrm{Ex} 2 / 3 \mathrm{p} 73 \mathrm{mRNAs} \text { were significantly upregulated in } \\
\text { melanoma metastases. } \\
\text { (ii) } \Delta \mathrm{Np} 73 \text { was the predominant isoform in benign nevi. } \\
\text { (iii) An increased expression of } \Delta \mathrm{Ex} 2 \mathrm{p} 73 \text { and } \Delta \mathrm{Ex} 2 / 3 \mathrm{p} 73 \text { isoforms } \\
\text { correlated with high levels of TAp } 73 \text { and E2F1. }\end{array}$ & $\begin{array}{l}8 \text { benign melanocytic nevi, } \\
8 \text { primary melanomas, and } \\
19 \text { melanoma metastases }\end{array}$ & {$[68]$} \\
\hline \multicolumn{4}{|c|}{ Gastric cancer } \\
\hline \multirow[t]{3}{*}{ p73 } & $\begin{array}{l}\text { (i) p73 expression was increased in } 37 / 39 \text { gastric carcinomas and } 14 / 16 \\
\text { matched sets. } \\
\text { (ii) No allelic deletions or mutations in the p73 gene were detected. } \\
\text { (iii) There was no association between p73 expression and mutational } \\
\text { status of p53 or expression of p21/Waf1. }\end{array}$ & 39 gastric carcinomas & {$[94]$} \\
\hline & $\begin{array}{l}\text { (i) p73 expression was found in } 33 / 68 \text { tumors from } 24 \text { patients with } \\
\text { multiple simultaneous gastric cancers. } \\
\text { (ii) No mutation in the DNA-binding domain of p } 73 \text { was found. } \\
\text { (iii) No correlations were found between p73 expression and clinical } \\
\text { variables. }\end{array}$ & $\begin{array}{l}68 \text { gastric carcinomas from } 32 \\
\text { patients }\end{array}$ & {$[95]$} \\
\hline & $\begin{array}{l}\text { (i) } \Delta \mathrm{Np} 73 \mathrm{mRNA} \text { and protein were increased in gastric tumors. } \\
\text { (ii) Up-regulation of } \Delta \mathrm{Np} 73 \text { protein was significantly associated with } \\
\text { poor patient survival. The median survival time for patients with } \\
\text { increased } \Delta \mathrm{Np} 73 \text { was } 20 \text { months whereas that of patients with a } \\
\text { negative/weak expression was } 47 \text { months. }\end{array}$ & 185 tumors & [96] \\
\hline \multirow[t]{2}{*}{ p63 } & $\begin{array}{l}\text { (i) p63 expression was found in } 25 / 68 \text { tumors from } 24 \text { patients with } \\
\text { multiple simultaneous gastric cancer. p63 expression was significantly } \\
\text { higher in high-grade diffuse tumors. An increased expression of p63 was } \\
\text { observed in intestinal metaplasia and atrophic gastritis. Nonneoplastic } \\
\text { tissues had low levels of p63. } \\
\text { (ii) Expression of TAp } 63 \text { and } \Delta \text { Np63 was not associated with the } \\
\text { mutational status of p53, tumor stage, or prognosis. }\end{array}$ & $\begin{array}{l}68 \text { gastric carcinomas from } \\
32 \text { patients }\end{array}$ & [95] \\
\hline & \multicolumn{3}{|l|}{ Esophageal Cancer } \\
\hline \multirow[t]{3}{*}{$\mathrm{p} 73$} & $\begin{array}{l}\text { (i) Low expression of p73 mRNA in } 8 \text { analyzed tumors. } \\
\text { (ii) No tumor-specific mutation was found. } \\
\text { (iii) LOH for p73 was found in } 2 / 25(8 \%) \text { tumors. }\end{array}$ & $\begin{array}{l}48 \text { esophageal tumors ( } 47 \text { ESCCs } \\
\text { and } 1 \text { EA) }\end{array}$ & {$[56]$} \\
\hline & $\begin{array}{l}\text { (i) LOH was found in } 9 / 14 \text { cases. } \\
\text { (ii) No mutations in the p } 73 \text { gene were detected in tumor samples. A } \\
\text { polymorphism at codon } 173 \text { of p } 73 \text { was identified. }\end{array}$ & \multirow[t]{2}{*}{15 ESCCs } & \multirow[t]{2}{*}{ [97] } \\
\hline & $\begin{array}{l}\text { (iii) p73 mRNA was overexpressed in } 9 / 15 \text { tumor samples. Four cases } \\
\text { showed loss of imprinting. Expression of p } 73 \text { correlated with p53 } \\
\text { mutations. }\end{array}$ & & \\
\hline
\end{tabular}


Table 1: Continued.

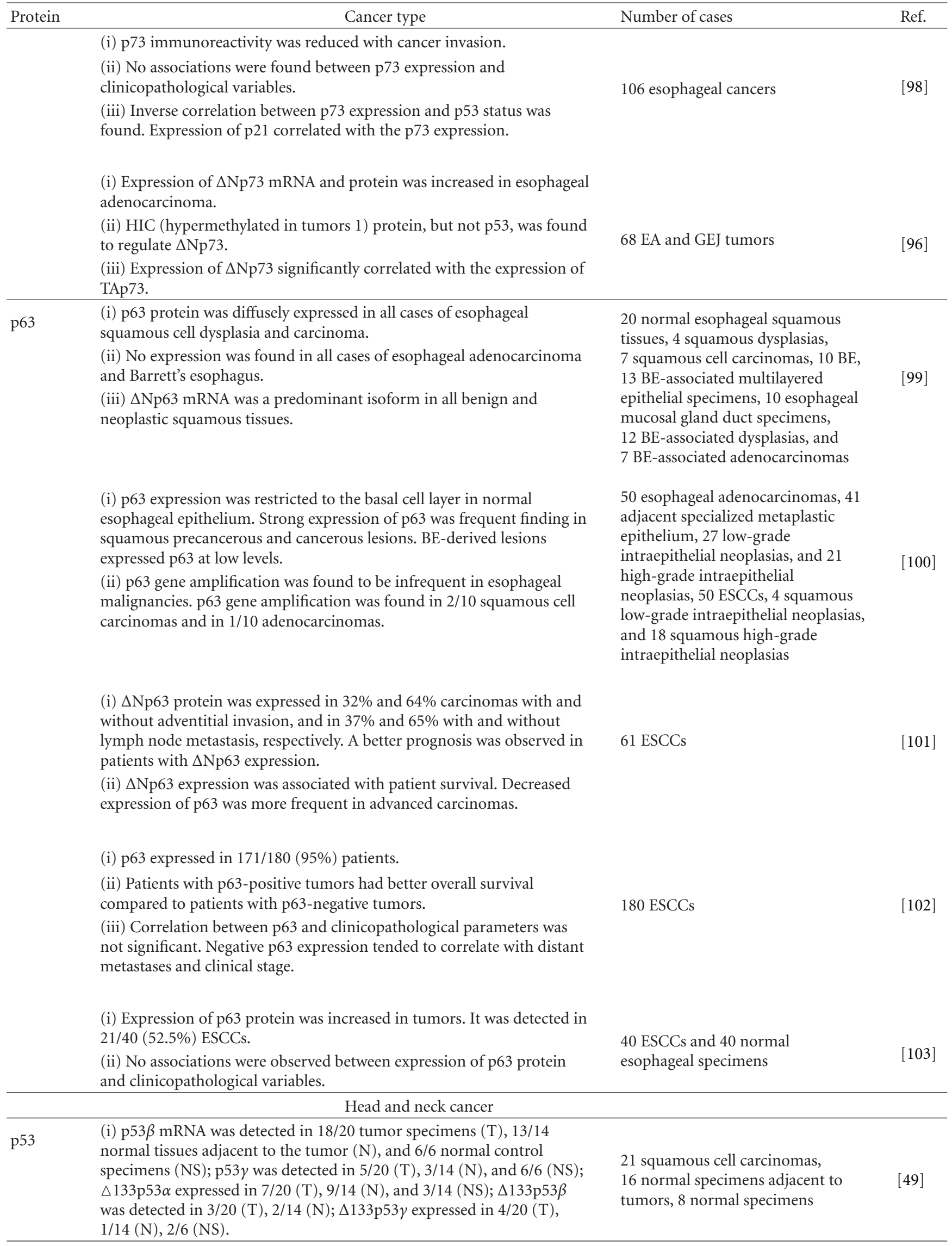


Table 1: Continued.

\begin{tabular}{|c|c|c|c|}
\hline Protein & Cancer type & Number of cases & Ref. \\
\hline \multirow[t]{4}{*}{ p73 } & $\begin{array}{l}\text { (i) Two missense mutations at codons } 469 \text { and } 477 \text { and one silent } \\
\text { mutation at codon } 349 \text { in the p73 gene were found. } \\
\text { (ii) Increased p73 expression was found in } 5 / 21(23.8 \%) \text { patients; } \\
\text { decreased expression was observed in } 6 / 21(28.5 \%) \text { patients. }\end{array}$ & $\begin{array}{l}67 \text { primary oral and laryngeal } \\
\text { squamous cell carcinomas }\end{array}$ & {$[104]$} \\
\hline & $\begin{array}{l}\text { (i) p } 73 \text { mRNA was decreased in } 5 / 17 \text { (30\%) tumors. No mutation and } \\
\text { LOH was found in the p } 73 \text { gene. } \\
\text { (ii) No correlation was found between p } 73 \text { and p53 protein expression. }\end{array}$ & 50 squamous cell carcinomas & {$[105]$} \\
\hline & $\begin{array}{l}\text { (i) p73 protein expression was detected in } 12 / 68(18 \%) \text { normal mucosas } \\
\text { and } 32 / 68(47 \%) \text { HNSCC. } \\
\text { (ii) No p73 mutations were found in primary and recurrent carcinomas. } \\
\text { (iii) No correlation was found between protein expression of p73 and } \\
\text { p53. }\end{array}$ & 68 squamous cell carcinomas & [106] \\
\hline & $\begin{array}{l}\text { (i) p73 was significantly elevated in buccal epithelial dysplasia (protein) } \\
\text { and squamous cell carcinomas (protein and mRNA) compared to } \\
\text { normal control tissues. } \\
\text { (ii) p73 expression was associated with cervical lymph node metastasis } \\
\text { for cases of buccal SCC. }\end{array}$ & $\begin{array}{l}25 \text { buccal squamous cell } \\
\text { carcinomas, } 75 \text { epithelial dysplasias }\end{array}$ & [107] \\
\hline \multirow[t]{3}{*}{ p63 } & $\begin{array}{l}\text { (i) Positive immunostaining for p63 was detected in } 55 / 68(81 \%) \\
\text { carcinomas, } 40 / 68 \text { (59\%) normal tissues. } \\
\text { (ii) No p63 mutations were detected in primary and recurrent } \\
\text { carcinomas. } \\
\text { (iii) No correlation was found between p63 and p53 protein expression. }\end{array}$ & 68 squamous cell carcinomas & [106] \\
\hline & $\begin{array}{l}\text { (i) Expression of p63 was associated with tumor differentiation. } \\
\text { p63 expression was increased in poorly differentiated tumors. } \\
\text { (ii) Increased p63 expression was associated with poor patient survival. } \\
\text { No significant correlations were found between p63 expression and sex, } \\
\text { age, tumor size, staging, recurrence, and metastasis. Tumors with diffuse } \\
\text { p63 expression were more aggressive and poorly differentiated. }\end{array}$ & $\begin{array}{l}96 \text { oral squamous cell carcinomas } \\
\text { and } 10 \text { normal specimens }\end{array}$ & {$[108]$} \\
\hline & Cervical cancer & & \\
\hline \multirow[t]{2}{*}{ p73 } & $\begin{array}{l}\text { (i) } \Delta \mathrm{Np} 73 \text { and TAp } 73 \alpha \text { proteins were overexpressed in tumors. } \\
\text { (ii) The overexpression of } \Delta \mathrm{Np} 73 \text { was correlated with the resistance to } \\
\text { radiation therapy. An increased expression of TAp } 73 \alpha \text { was detected in } \\
\text { the majority of cervical squamous cell carcinomas sensitive to } \\
\text { irradiation. } \\
\text { (iii) } \Delta \mathrm{Np} 73 \text { expression was associated with recurrence of the disease and } \\
\text { an adverse outcome. TAp } 73 \alpha \text { predicted a better survival. }\end{array}$ & $\begin{array}{l}117 \text { cervical squamous cell } \\
\text { carcinomas and } 113 \text { normal } \\
\text { specimens }\end{array}$ & [109] \\
\hline & $\begin{array}{l}\text { (i) Higher TAp73 expression was found in high-grade lesions and } \\
\text { carcinomas }(P<.0001) \text {. } \\
\text { (ii) No correlation was found between p73 and p63 immunostainings. }\end{array}$ & $\begin{array}{l}91 \text { high-grade and } 107 \text { low-grade } \\
\text { squamous intraepithelial lesions, } 212 \\
\text { ASC-US, } 56 \text { squamous cell } \\
\text { carcinomas, and } 63 \text { normal specimens }\end{array}$ & {$[110]$} \\
\hline \multirow[t]{2}{*}{ p63 } & $\begin{array}{l}\text { (i) Expression of p } 63 \text { protein was high in } 97 \% \text { squamous cell } \\
\text { carcinomas. p63 is a strong marker for squamous differentiation. } \\
\text { (ii) Transitions from squamous to columnar or undifferentiated tumors } \\
\text { coincided with the loss of p63 expression. } \\
\text { (iii) HPV16 positivity and p63 expression were strong associated. }\end{array}$ & 250 cervical carcinomas & {$[111]$} \\
\hline & $\begin{array}{l}\text { (i) } \Delta \text { Np63 staining was increased with tumor progression. All SCCs, } \\
\text { transitional cell carcinomas, and adenoid basal carcinomas were positive } \\
\text { for p63. } \\
\text { (ii) } \Delta \text { Np63 protein was undetected in all adenocarcinomas. }\end{array}$ & $\begin{array}{l}127 \text { uterine cervical tissues with } \\
\text { various lesions }\end{array}$ & {$[112]$} \\
\hline
\end{tabular}


TABle 1: Continued.

\begin{tabular}{|c|c|c|c|}
\hline Protein & Cancer type & Number of cases & Ref. \\
\hline & $\begin{array}{l}\text { (i) Increased p63 immunostaining was found in high-grade lesions and } \\
\text { cervical carcinomas. }\end{array}$ & \multirow{3}{*}{$\begin{array}{l}91 \text { high-grade and } 107 \text { low-grade } \\
\text { squamous intraepithelial lesions, } \\
212 \text { ASC-US, } 56 \text { squamous cell } \\
\text { carcinomas, and } 63 \text { normal } \\
\text { specimens }\end{array}$} & \multirow{3}{*}[110]{} \\
\hline & $\begin{array}{l}\text { (ii) Significant correlation was found between the presence of high-risk } \\
\text { HPV and p63 expression. }\end{array}$ & & \\
\hline & (iii) No correlation was found between p63 and p73 immunostainings. & & \\
\hline \multicolumn{4}{|c|}{ Renal cancer } \\
\hline p53 & $\begin{array}{l}\text { (i) All six p53 isoforms were detected in tumor and normal tissues with } \\
\text { the exception of } \Delta 133 \mathrm{p} 53 \beta \text {, which was not detected in normal tissues. }\end{array}$ & \multirow{2}{*}{$\begin{array}{l}41 \text { renal cell carcinomas and normal } \\
\text { tissues adjacent to tumor }\end{array}$} & \multirow[b]{2}{*}[47]{} \\
\hline & $\begin{array}{l}\text { (ii) } \mathrm{p} 53 \beta \mathrm{mRNA} \text { was significantly upregulated in tumor samples } \\
(P<.001) \text { and associated with tumor stage. }\end{array}$ & & \\
\hline p73 & $\begin{array}{l}\text { (i) Monoallelic expression of p } 73 \text { was found in } 11 / 12 \text { normal tissues; } \\
\text { biallelic expression in } 8 / 12 \text { cancers. }\end{array}$ & 28 renal cell carcinomas & [113] \\
\hline \multirow[t]{2}{*}{ p63 } & $\begin{array}{l}\text { (i) p63 expression was detected in } 25 / 27 \text { ( } 92.6 \%) \text { urothelial carcinomas. } \\
\text { None of the studied renal cell carcinomas was positive for p63. p63 } \\
\text { expression correlated with tumor stage, grade and survival time, but not } \\
\text { with the tumor progression. }\end{array}$ & $\begin{array}{l}42 \text { renal cell carcinomas and } 27 \\
\text { renal pelvis urothelial carcinomas }\end{array}$ & {$[114]$} \\
\hline & Thyroid cancer & & \\
\hline \multirow[t]{2}{*}{ p73 } & $\begin{array}{l}\text { (i) p73 transcripts were downregulated in adenomas and differentiated } \\
\text { carcinomas. }\end{array}$ & \multirow[b]{2}{*}{102 thyroid tissues from 60 patients } & \multirow[b]{2}{*}[115]{} \\
\hline & $\begin{array}{l}\text { (ii) Expression of TAp73 and } \Delta \mathrm{Np} 73 \text { transcripts correlated with } \\
\text { expression of p53, p14ARF, and p16INK4a mRNA in normal tissue. }\end{array}$ & & \\
\hline
\end{tabular}

These correlations were lost in carcinomas.

(i) $\Delta$ Np73 was expressed in $27.3 \%$ follicular adenomas, $85.4 \%$ follicular carcinomas, $99.2 \%$ papillary carcinomas, and $95.7 \%$ anaplastic carcinomas. Normal follicular cells were negative for $\Delta \mathrm{Np} 73$ protein. In papillary carcinoma, $\Delta \mathrm{Np} 73$ levels were inversely correlated with tumor size, extrathyroid extensions, and metastases. In anaplastic carcinoma, $\Delta$ Np73 expression was significantly lower than in papillary carcinoma.

p63 (i) TAp63 $\alpha$ protein was expressed in $25 / 27$ thyroid cancers $1 / 7$ benign adenomas, but not in normal thyroid (0/8). TAp63 $\alpha$ transcripts, but not TAp63 $\beta$, TAp63 $\gamma$, and $\Delta \mathrm{Np} 63$, were expressed in tumors. Thyroid cancer cell lines also expressed $\mathrm{p} 63$.

$$
\text { Pancreatic cancer }
$$

p73 (i) Expression of p73 protein was detected in $45.6 \%$ cancers and was primarily found in cystic adenocarcinomas.

(ii) p73 expression was inversely correlated with lymph node metastasis, tumor size, and Ki-67 labeling index.

(iii) No correlation was found between $\mathrm{p} 73$ and p53 protein expression.

(i) p73 methylation was found in more than $50 \%$ noninvasive and invasive tumors.

28 intraductal papillary mucinous neoplasms

(i) Overexpression of p63 protein was observed in $68.2 \%$ cancers.

(ii) p63 expression was not associated with clinicopathological variables.

(iii) No correlation was found between p63 and p53 protein expression.

(i) No $\Delta$ Np63 protein expression was found in normal pancreatic ducts and all pancreatic intraepithelial neoplasias. Among invasive carcinomas, $\Delta \mathrm{Np} 63$ expression was detected only in areas of squamous differentiation and was completely absent in ordinary ductal areas. $\Delta \mathrm{Np} 63$ is a reliable marker of squamous differentiation in the pancreas. It was valuable in distinguishing squamous/transitional metaplasia from PanINs.
25 nonneoplastic pancreata, 25 pancreatic intraepithelial neoplasia, and 50 pancreatic ductal adenocarcinomas 


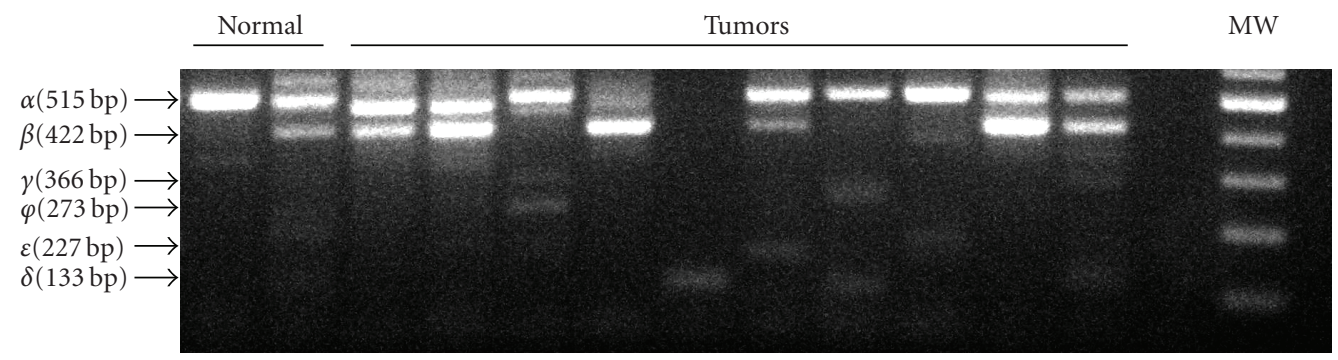

FIGURE 3: An increased diversity of alternatively spliced species of p73 in colon adenocarcinoma. p73 gene transcription was analyzed in 10 colon tumors and normal colonic mucosa by RT-PCR. Normal specimen 2 represents 14 pooled normal samples. For details, see Vilgelm et al. [15].

mature myeloid cells [136]. It is currently unclear what role these changes play in tumorigenesis.

\section{Role of p63 Isoforms in Cancer}

Similar to p73, mutations in the p63 gene are rare in human cancers $[90,137,138]$. Several studies reported that $\Delta N p 63$ has oncogenic properties. Ectopic overexpression of $\Delta \mathrm{Np} 63$ in Rat-1A cells promotes colony formation in soft agar. When xenografted into immunocompromised mice, these cells formed tumors [139]. $\Delta \mathrm{Np} 63 \alpha$ inhibits oncogene-induced cellular senescence and cooperates with Ras to promote tumor-initiating stem-like proliferation [140]. Analysis of p63-deficient mice led to conflicting results with regard to the p63 role in tumorigenesis. p63 ${ }^{-/-}$null mice showed striking developmental defects demonstrating a critical role of p63 in epithelial development $[141,142]$. p $63^{+/-}$heterozygous mice were shown to be susceptible to tumor development [143]. However, other mouse models were not consistent with this observation. Conflicting phenotypes of TAp63 and $\Delta \mathrm{Np} 63$ transgenic mice have also been reported [144, 145].

$\Delta \mathrm{Np} 63$ is a predominant isoform expressed in most epithelial cells. Overexpression of $\Delta \mathrm{Np} 63$ is found in cancers of nasopharyngeal, head and neck, urinary tract, lung, and ovarian tumors and correlated with poor outcome [78, 146149]. In metastases, $\Delta \mathrm{Np} 63$ expression was found to be reduced or lost $[91,101]$. Microarray analyses revealed the up-regulation of genes associated with tumor invasion and metastasis in p63-deficient cells [150]. It was also reported that p63 suppresses the TGF $\beta$-dependent cell migration, invasion, and metastasis [151]. This suggests that $\Delta \mathrm{Np} 63$ plays a dual role by promoting tumor development but suppressing metastases $[151,152]$. Expression of $\Delta \mathrm{Np} 63$ was found to be associated with an increased chemoresistance in a subset of breast and head and neck tumors [153, 154].

TAp63 isoforms induce cellular senescence and inhibit cell proliferation [155-157]. TAp63 deficiency increases proliferation and enhances Ras-mediated oncogenesis [155]. Decreased TAp63 expression is associated with metastasis in bladder and breast cancers as well as poor outcome $[42,90,158]$. TAp63 impedes the metastatic potential of epithelial tumors by controlling the expression of a crucial set of metastasis suppressor genes [151, 159].
Clearly, additional studies are needed to understand the complex regulation of p63 isoforms.

\section{Interplay of p53/p63/p73 Isoforms in Human Cancers}

Interactions between members of the p53 family and their isoforms have a profound effect on tumorigenesis and anticancer drug response. Perhaps, the most studied are interactions between $\Delta \mathrm{N}$ and $\mathrm{TA}$ isoforms. Inhibition of TAp73 by $\Delta$ Np63 has been shown to negatively affect the response to platinum-based chemotherapy in head and neck squamous cell carcinomas and a subset of breast tumors [153, 154]. In carcinomas of ovary and childhood acute lymphoblastic leukemia, increased expression of dominant-negative p73 isoforms correlates with resistance to conventional chemotherapy $[129,130]$. Moreover, $\triangle \mathrm{Np} 73$ is primarily expressed in ovarian tumors, which express wildtype p53 [64]. However, crosstalk between the p53 family members is not limited to dominant-negative interactions. Accumulating evidence suggests that the p53 family interacts on multiple levels comprising proteinprotein interactions between multiple p53, p63, and p73 isoforms, shared regulation of target genes as well as TP53 and TP73 gene promoters [160-163]. In addition, mutant p53 can affect activities of TAp73 and TAp63. It has been shown that certain tumor-derived p53 mutants (R175H, R248W, Y220C, R249S, R283H, and D281G) can physically associate and inhibit activation of TAp73 and/or TAp63 [164-166].

Current analyses suggest that the function of a particular isoform needs to be investigated in the context of expression of other isoforms. For example, $\Delta \mathrm{Np} 73 \beta$ inhibits p53dependent apoptosis in primary sympathetic neurons [167], but when overexpressed in cancer cells, $\Delta \mathrm{Np} 73 \beta$ induces cell cycle arrest and apoptosis [168].

An interesting observation has been made in mouse embryonic fibroblasts, where the combined loss of p73 and p63 results in the failure of p53 to induce apoptosis in response to DNA damage [169]. More recent studies have reported that the p53 family members can simultaneously co-occupy the promoters of p53 target genes and regulate their transcription $[15,170,171]$. Notably, the integral activity of the entire p53 family, as measured by reporter 
analysis, is a better predictor of chemotherapeutic drug response than $\mathrm{p} 53$ status alone [15].

\section{Conclusion}

The p53 family plays a pivotal role in the control of many critical cellular functions. In recent years, it has been revealed that all members of the p53 family are expressed as a diverse variety of isoforms. We only just started to uncover the mechanisms that regulate this diversity. A number of studies also provided the first glimpses of their functional significance. Clearly, isoforms add a new level of functional regulation to many critical biological processes including cell death, proliferation, cell cycle control, and tumorigenesis. Depending on the isoform expressed, the role of a gene can dramatically change from a tumor suppressor to an oncogene. It is also clear that p53, p73, and p63 isoforms tightly interact. A better understanding of this interacting network and its regulation holds the key to future therapeutic benefits.

\section{Acknowledgments}

The authors thank Dr. El-Rifai for the valuable discussions. This paper was supported by the National Cancer Institute Grants NIH CA138833 and NIH CA108956.

\section{References}

[1] E. T. Wang, R. Sandberg, S. Luo et al., "Alternative isoform regulation in human tissue transcriptomes," Nature, vol. 456, no. 7221, pp. 470-476, 2008.

[2] Q. Pan, Q. Shai, L. J. Lee, B. J. Frey, and B. J. Blencowe, "Deep surveying of alternative splicing complexity in the human transcriptome by high-throughput sequencing," Nature Genetics, vol. 40, no. 12, pp. 1413-1415, 2008.

[3] R. Klinck, A. Bramard, L. Inkel et al., "Multiple alternative splicing markers for ovarian cancer," Cancer Research, vol. 68, no. 3, pp. 657-663, 2008.

[4] J. P. Venables, R. Klinck, C. Koh et al., "Cancer-associated regulation of alternative splicing," Nature Structural and Molecular Biology, vol. 16, no. 6, pp. 670-676, 2009.

[5] J. C. Bourdon, K. Fernandes, F. Murray-Zmijewski et al., "p53 isoforms can regulate p53 transcriptional activity," Genes and Development, vol. 19, no. 18, pp. 2122-2137, 2005.

[6] V. Dötsch, F. Bernassola, D. Coutandin, E. Candi, and G. Melino, "p63 and p73, the ancestors of p53," Cold Spring Harbor perspectives in biology, vol. 2, no. 9, p. a004887, 2010.

[7] R. Rutkowski, K. Hofmann, and A. Gartner, "Phylogeny and function of the invertebrate p53 superfamily," Cold Spring Harbor Perspectives in Biology, vol. 2, no. 7, Article ID a001131, 2010.

[8] B. Petre-Lazar, G. Livera, S. G. Moreno et al., "The role of p63 in germ cell apoptosis in the developing testis," Journal of Cellular Physiology, vol. 210, no. 1, pp. 87-98, 2007.

[9] M. Kaghad, H. Bonnet, A. Yang et al., "Monoallelically expressed gene related to $\mathrm{p} 53$ at $1 \mathrm{p} 36$, a region frequently deleted in neuroblastoma and other human cancers," Cell, vol. 90, no. 4, pp. 809-819, 1997.

[10] A. Yang, M. Kaghad, Y. Wang et al., "p63, a p53 homolog at 3q27-29, encodes multiple products with transactivating, death-inducing, and dominant-negative activities," Molecular Cell, vol. 2, no. 3, pp. 305-316, 1998.

[11] G. Melino, X. Lu, M. Gasco, T. Crook, and R. A. Knight, "Functional regulation of p73 and p63: development and cancer," Trends in Biochemical Sciences, vol. 28, no. 12, pp. 663-670, 2003.

[12] D. P. Lane and L. V. Crawford, "T antigen is bound to a host protein in SV40 transformed cells," Nature, vol. 278, no. 5701, pp. 261-263, 1979.

[13] D. I. H. Linzer and A. J. Levine, "Characterization of a $54 \mathrm{~K}$ dalton cellular SV40 tumor antigen present in SV40 transformed cells and uninfected embryonal carcinoma cells," Cell, vol. 17, no. 1, pp. 43-52, 1979.

[14] A. E. Sayan, M. Rossi, G. Melino, and R. A. Knight, "p73: in silico evidence for a putative third promoter region," Biochemical and Biophysical Research Communications, vol. 313, no. 3, pp. 765-770, 2004.

[15] A. E. Vilgelm, M. K. Washington, J. Wei, H. Chen, V. S. Prassolov, and A. I. Zaika, "Interactions of the p53 protein family in cellular stress response in gastrointestinal tumors," Molecular Cancer Therapeutics, vol. 9, no. 3, pp. 693-705, 2010.

[16] A. Yang and F. McKeon, "p63 and p73: p53 mimics, menaces and more," Nature Reviews Molecular Cell Biology, vol. 1, no. 3, pp. 199-207, 2000.

[17] T. Stiewe, C. C. Theseling, and B. M. Pützer, "Transactivation-deficient $\Delta$ TA-p73 inhibits p53 by direct competition for DNA binding. Implications for tumorigenesis," Journal of Biological Chemistry, vol. 277, no. 16, pp. 14177-14185, 2002.

[18] O. Ishimoto, C. Kawahara, K. Enjo, M. Obinata, T. Nukiwa, and S. Ikawa, "Possible oncogenic potential of $\Delta \mathrm{Np} 73$ : a newly identified isoform of human p73," Cancer Research, vol. 62, no. 3, pp. 636-641, 2002.

[19] Y. Yin, C. W. Stephen, M. G. Luciani, and R. Fåhraeus, "p53 stability and activity is regulated by Mdm2-mediated induction of alternative p53 translation products," Nature Cell Biology, vol. 4, no. 6, pp. 462-467, 2002.

[20] S. Courtois, G. Verhaegh, S. North et al., " $\Delta$ N-p53, a natural isoform of p53 lacking the first transactivation domain, counteracts growth suppression by wild-type p53," Oncogene, vol. 21, no. 44, pp. 6722-6728, 2002.

[21] V. Marcel, S. Perrier, M. Aoubala et al., " $\Delta 160 \mathrm{p} 53$ is a novel N-terminal p53 isoform encoded by $\Delta 133$ p53 transcript," FEBS Letters, vol. 584, no. 21, pp. 4463-4468, 2010.

[22] A. Zaika, M. Irwin, C. Sansome, and U. M. Moll, "Oncogenes induce and activate endogenous p73 protein," Journal of Biological Chemistry, vol. 276, no. 14, pp. 11310-11316, 2001.

[23] A. I. Zaika, S. Kovalev, N. D. Marchenko, and U. M. Moll, "Overexpression of the wild type p73 gene in breast cancer tissues and cell lines," Cancer Research, vol. 59, no. 13, pp. 3257-3263, 1999.

[24] V. de Laurenzi, M. V. Catani, A. Terrinoni et al., "Additional complexity in p73: induction by mitogens in lymphoid cells and identification of two new splicing variants $\varepsilon$ and $\zeta$," Cell Death and Differentiation, vol. 6, no. 5, pp. 389-390, 1999.

[25] Y. Ueda, M. Hijikata, S. Takagi, T. Chiba, and K. Shimotohno, "New p73 variants with altered C-terminal structures have varied transcriptional activities," Oncogene, vol. 18, no. 35, pp. 4993-4998, 1999.

[26] H. Vanbokhoven, G. Melino, E. Candi, and W. Declercq, "p63, a story of mice and men," Journal of Investigative Dermatology, vol. 131, no. 6, pp. 1196-1207, 2011. 
[27] M. Mangiulli, A. Valletti, M. F. Caratozzolo et al., "Identification and functional characterization of two new transcriptional variants of the human p63 gene," Nucleic Acids Research, vol. 37, no. 18, pp. 6092-6104, 2009.

[28] G. Hofstetter, A. Berger, H. Fiegl et al., "Alternative splicing of p53 and p73: the novel p53 splice variant p53 is an independent prognostic marker in ovarian cancer," Oncogene, vol. 29, no. 13, pp. 1997-2004, 2010.

[29] M. Dohn, S. Zhang, and X. Chen, "p63 $\alpha$ and $\Delta \mathrm{Np} 63 \alpha$ can induce cell cycle arrest and apoptosis and differentially regulate p53 target genes," Oncogene, vol. 20, no. 25, pp. 3193-3205, 2001.

[30] K. Tomkova, A. Belkhiri, W. El-Rifai, and A. I. Zaika, "p73 isoforms can induce T-cell factor-dependent transcription in gastrointestinal cells," Cancer Research, vol. 64, no. 18, pp. 6390-6393, 2004.

[31] M. Sauer, A. C. Bretz, R. Beinoraviciute-Kellner et al., "C-terminal diversity within the p53 family accounts for differences in DNA binding and transcriptional activity," Nucleic Acids Research, vol. 36, no. 6, pp. 1900-1912, 2008.

[32] V. Graupner, K. Schulze-Osthoff, F. Essmann, and R. U. Jänicke, "Functional characterization of p $53 \beta$ and p $53 \gamma$, two isoforms of the tumor suppressor p53," Cell Cycle, vol. 8, no. 8, pp. 1238-1248, 2009.

[33] K. A. Avery-Kiejda, D. Z. Xu, L. J. Adams et al., "Small molecular weight variants of $\mathrm{p} 53$ are expressed in human melanoma cells and are induced by the DNA-damaging agent cisplatin," Clinical Cancer Research, vol. 14, no. 6, pp. 16591668, 2008.

[34] T. Nakagawa, M. Takahashi, T. Ozaki et al., "Autoinhibitory regulation of $\mathrm{p} 73$ by $\Delta \mathrm{Np} 73$ to modulate cell survival and death through a p73-specific target element within the $\triangle \mathrm{Np73}$ promoter," Molecular and Cellular Biology, vol. 22, no. 8, pp. 2575-2585, 2002.

[35] A. I. Zaika, N. Slade, S. H. Erster et al., " $\delta N p 73$, a dominant-negative inhibitor of wild-type p53 and TAp73, is up-regulated in human tumors," Journal of Experimental Medicine, vol. 196, no. 6, pp. 765-780, 2002.

[36] H. C. Moore, L. B. Jordan, S. E. Bray et al., "The RNA helicase p68 modulates expression and function of the $\Delta 133$ isoform(s) of p53, and is inversely associated with $\Delta 133 \mathrm{p} 53$ expression in breast cancer," Oncogene, vol. 29, no. 49, pp. 6475-6484, 2010.

[37] V. Marcel, V. Vijayakumar, L. Fernández-Cuesta et al., "P53 regulates the transcription of its $\Delta 133 \mathrm{p} 53$ isoform through specific response elements contained within the TP53 P2 internal promoter," Oncogene, vol. 29, no. 18, pp. 2691-2700, 2010.

[38] M. Aoubala, F. Murray-Zmijewski, M. P. Khoury et al., "p53 directly transactivates $\Delta 133 \mathrm{p} 53 \alpha$, regulating cell fate outcome in response to DNA damage," Cell Death and Differentiation, vol. 18, no. 2, pp. 248-258, 2010.

[39] T. J. Grob, U. Novak, C. Maisse et al., "Human $\Delta \mathrm{Np} 73$ regulates a dominant negative feedback loop for TAp73 and p53," Cell Death and Differentiation, vol. 8, no. 12, pp. 12131223, 2001.

[40] D. A. Arvanitis, E. Lianos, N. Soulitzis, D. Delakas, and D. A. Spandidos, "Deregulation of p73 isoform equilibrium in benign prostate hyperplasia and prostate cancer," Oncology Reports, vol. 12, no. 5, pp. 1131-1137, 2004.

[41] R. Malaguarnera, V. Vella, R. Vigneri, and F. Frasca, "p53 family proteins in thyroid cancer," Endocrine-Related Cancer, vol. 14, no. 1, pp. 43-60, 2007.
[42] M. L. Iacono, V. Monica, S. Saviozzi et al., "p63 and p73 isoform expression in non-small cell lung cancer and corresponding morphological normal lung tissue," Journal of Thoracic Oncology, vol. 6, no. 3, pp. 473-481, 2011.

[43] T. L. Slatter, N. Hung, H. Campbell et al., "Hyperproliferation, cancer, and inflammation in mice expressing a $\Delta$ 133p53-like isoform," Blood, vol. 117, no. 19, pp. 51665177, 2011.

[44] B. Maier, W. Gluba, B. Bernier et al., "Modulation of mammalian life span by the short isoform of p53," Genes and Development, vol. 18, no. 3, pp. 306-319, 2004.

[45] M. Pehar, K. J. O’Riordan, M. Burns-Cusato et al., "Altered longevity-assurance activity of p53:p44 in the mouse causes memory loss, neurodegeneration and premature death," Aging Cell, vol. 9, no. 2, pp. 174-190, 2010.

[46] E. Ungewitter and H. Scrable, " $\Delta 40 \mathrm{p} 53$ controls the switch from pluripotency to differentiation by regulating IGF signaling in ESCs," Genes and Development, vol. 24, no. 21, pp. 2408-2419, 2010.

[47] W. Song, S. W. Huo, J. J. Lü et al., "Expression of p53 isoforms in renal cell carcinoma," Chinese Medical Journal, vol. 122, no. 8, pp. 921-926, 2009.

[48] K. Fujita, A. M. Mondal, I. Horikawa et al., "p53 isoforms $\Delta 133$ p53 and p $53 \beta$ are endogenous regulators of replicative cellular senescence," Nature Cell Biology, vol. 11, no. 9, pp. 1135-1142, 2009.

[49] L. Boldrup, J. C. Bourdon, P. J. Coates, B. Sjöström, and K. Nylander, "Expression of p53 isoforms in squamous cell carcinoma of the head and neck," European Journal of Cancer, vol. 43, no. 3, pp. 617-623, 2007.

[50] J.-C. Bourdon, M. P. Khoury, A. Diot et al., "p53 mutant breast cancer patients expressing p53gamma have as good a prognosis as wild-type p53 breast cancer patients," Breast Cancer Research, vol. 13, no. 1, article R7, 2011.

[51] C. B. Dugani, A. Paquin, M. Fujitani, D. R. Kaplan, and F. D. Miller, "p63 antagonizes p53 to promote the survival of embryonic neural precursor cells," Journal of Neuroscience, vol. 29, no. 20, pp. 6710-6721, 2009.

[52] D. I. Schwartz, N. M. Lindor, C. Walsh-Vockley et al., "p73 mutations are not detected in sporadic and hereditary breast cancer," Breast Cancer Research and Treatment, vol. 58, no. 1, pp. 25-29, 1999.

[53] S. Kovalev, N. Marchenko, S. Swendeman, M. LaQuaglia, and U. M. Moll, "Expression level, allelic origin, and mutation analysis of the p73 gene in neuroblastoma tumors and cell lines," Cell Growth and Differentiation, vol. 9, no. 11, pp. 897903, 1998.

[54] M. Mai, H. Huang, C. Reed et al., "Genomic organization and mutation analysis of p73 in oligodendrogliomas with chromosome 1 p-arm deletions," Genomics, vol. 51, no. 3, pp. 359-363, 1998.

[55] A. Yokomizo, M. Mai, D. J. Tindall et al., "Overexpression of the wild type p73 gene in human bladder cancer," Oncogene, vol. 18, no. 8, pp. 1629-1633, 1999.

[56] Y. Nimura, M. Mihara, S. Ichimiya et al., "p73, a gene related to p53, is not mutated in esophageal carcinomas," International Journal of Cancer, vol. 78, no. 4, pp. 437-440, 1998.

[57] A. Yang, N. Walker, R. Bronson et al., "p73-Deficient mice have neurological, pheromonal and inflammatory defects but lack spontaneous tumours," Nature, vol. 404, no. 6773, pp. 99-103, 2000.

[58] R. Tomasini, K. Tsuchihara, M. Wilhelm et al., "TAp73 knockout shows genomic instability with infertility and 
tumor suppressor functions," Genes and Development, vol. 22, no. 19, pp. 2677-2691, 2008.

[59] M. T. Wilhelm, A. Rufini, M. K. Wetzel et al., "Isoformspecific p73 knockout mice reveal a novel role for $\Delta \mathrm{Np} 73$ in the DNA damage response pathway," Genes and Development, vol. 24, no. 6, pp. 549-560, 2010.

[60] A. Tannapfel, K. John, N. Miše et al., "Autonomous growth and hepatocarcinogenesis in transgenic mice expressing the p53 family inhibitor DNp73," Carcinogenesis, vol. 29, no. 1, pp. 211-218, 2008.

[61] T. Stiewe, S. Tuve, M. Peter, A. Tannapfel, A. H. Elmaagacli, and B. M. Pützer, "Quantitative TP73 transcript analysis in hepatocellular carcinomas," Clinical Cancer Research, vol. 10, no. 2, pp. 626-633, 2004.

[62] G. Domínguez, J. M. García, C. Peña et al., “ $\Delta$ TAp73 upregulation correlates with poor prognosis in human tumors: putative in vivo network involving p73 isoforms, p53, and E2F-1," Journal of Clinical Oncology, vol. 24, no. 5, pp. 805$815,2006$.

[63] I. Fillippovich, N. Sorokina, M. Gatei et al., "Transactivationdeficient $\mathrm{p} 73 \alpha$ (p73 $\Delta$ exon 2$)$ inhibits apoptosis and competes with p53," Oncogene, vol. 20, no. 4, pp. 514-522, 2001.

[64] N. Concin, K. Becker, N. Slade et al., "Transdominant $\triangle \mathrm{TAp} 73$ isoforms are frequently up-regulated in ovarian cancer. Evidence for their role as epigenetic p53 inhibitors in vivo," Cancer Research, vol. 64, no. 7, pp. 2449-2460, 2004.

[65] J. Castillo, S. Goñi, M. U. Latasa et al., "Amphiregulin induces the alternative splicing of p73 into its oncogenic isoform $\Delta \mathrm{Ex} 2 \mathrm{p} 73$ in human hepatocellular tumors," Gastroenterology, vol. 137, no. 5, pp. 1805-1815, article e4, 2009.

[66] S. W. Ng, G. K. Yiu, Y. Liu et al., "Analysis of p73 in human borderline and invasive ovarian tumor," Oncogene, vol. 19, no. 15, pp. 1885-1890, 2000.

[67] J. O’Nions, L. A. Brooks, A. Sullivan et al., "p73 is overexpressed in vulval cancer principally as the $\delta 2$ isoform," British Journal of Cancer, vol. 85, no. 10, pp. 1551-1556, 2001.

[68] S. Tuve, S. N. Wagner, B. Schitrek, and B. M. Pützer, "Alterations of $\Delta \mathrm{TA}-\mathrm{p} 73$ splice transcripts during melanoma development and progression," International Journal of Cancer, vol. 108, no. 1, pp. 162-166, 2004.

[69] T. Shishikura, S. Ichimiya, T. Ozaki et al., "Mutational analysis of the p73 gene in human breast cancers," International Journal of Cancer, vol. 84, no. 3, pp. 321-325, 1999.

[70] M. M. Koker and C. G. Kleer, "p63 expression in breast cancer: a highly sensitive and specific marker of metaplastic carcinoma," American Journal of Surgical Pathology, vol. 28, no. 11, pp. 1506-1512, 2004.

[71] A. Ribeiro-Silva, L. N. Z. Ramalho, S. B. Garcia, and S. Zucoloto, "Does the correlation between EBNA-1 and p63 expression in breast carcinomas provide a clue to tumorigenesis in Epstein-Barr virus-related breast malignancies?" Brazilian Journal of Medical and Biological Research, vol. 37, no. 1, pp. 89-95, 2004.

[72] L. Hanker, T. Karn, E. Ruckhaeberle et al., "Clinical relevance of the putative stem cell marker p63 in breast cancer," Breast Cancer Research and Treatment, vol. 122, no. 3, pp. 765-775, 2010.

[73] Y. Tokuchi, T. Hashimoto, Y. Kobayashi et al., "The expression of p73 is increased in lung cancer, independent of p53 gene alteration," British Journal of Cancer, vol. 80, no. 10, pp. 1623-1629, 1999.

[74] H. Uramoto, K. Sugio, T. Oyama et al., "Expression of $\Delta \mathrm{Np} 73$ predicts poor prognosis in lung cancer," Clinical Cancer Research, vol. 10, no. 20, pp. 6905-6911, 2004.
[75] A. Di Vinci, F. Sessa, I. Casciano et al., "Different intracellular compartmentalization of TA and $\Delta \mathrm{Np} 73$ in non-small cell lung cancer," International Journal of Oncology, vol. 34, no. 2, pp. 449-456, 2009.

[76] A. Daskalos, S. Logotheti, S. Markopoulou et al., "Global DNA hypomethylation-induced $\Delta \mathrm{Np} 73$ transcriptional activation in non-small cell lung cancer," Cancer Letters, vol. 300, no. 1, pp. 79-86, 2011.

[77] G. Pelosi, F. Pasini, C. O. Stenholm et al., "p63 immunoreactivity in lung cancer: yet another player in the development of squamous cell carcinomas?" Journal of Pathology, vol. 198, no. 1, pp. 100-109, 2002.

[78] P. P. Massion, P. M. Taflan, S. M. J. Rahman et al., "Significance of p63 amplification and overexpression in lung cancer development and prognosis," Cancer Research, vol. 63, no. 21, pp. 7113-7121, 2003.

[79] F. Chen, H. Chen, H. Tao, Y. Zhang, B. Ye, and M. Liu, "Different expressions of p53 gene family members and their clinical significance in human non-small cell lung cancer," Zhongguo Fei Ai Za Zhi, vol. 7, no. 4, pp. 339-343, 2004.

[80] T. Iwata, H. Uramoto, K. Sugio et al., "A lack of prognostic significance regarding $\triangle \mathrm{Np} 63$ immunoreactivity in lung cancer," Lung Cancer, vol. 50, no. 1, pp. 67-73, 2005.

[81] T. Narahashi, T. Niki, T. Wang et al., "Cytoplasmic localization of p63 is associated with poor patient survival in lung adenocarcinoma," Histopathology, vol. 49, no. 4, pp. 349-357, 2006.

[82] A. Yokomizo, M. Mai, D. G. Bostwick et al., "Mutation and expression analysis of the p73 gene in prostate cancer," Prostate, vol. 39, no. 2, pp. 94-100, 1999.

[83] M. Guan and Y. Chen, "Aberrant expression of $\Delta \mathrm{Np} 73$ in benign and malignant tumours of the prostate: correlation with Gleason score," Journal of Clinical Pathology, vol. 58, no. 11, pp. 1175-1179, 2005.

[84] J. K. Parsons, E. A. Saria, M. Nakayama et al., "Comprehensive mutational analysis and mRNA isoform quantification of TP63 in normal and neoplastic human prostate cells," Prostate, vol. 69, no. 5, pp. 559-569, 2009.

[85] P. K. Dhillon, M. Barry, M. J. Stampfer et al., "Aberrant cytoplasmic expression of p63 and prostate cancer mortality," Cancer Epidemiology Biomarkers and Prevention, vol. 18, no. 2, pp. 595-600, 2009.

[86] M. Guan, H. X. Peng, B. Yu, and Y. Lu, "p73 overexpression and angiogenesis in human colorectal carcinoma," Japanese Journal of Clinical Oncology, vol. 33, no. 5, pp. 215-220, 2003.

[87] F. P. Carneiro, L. N. Z. Ramalho, S. Britto-Garcia, A. RibeiroSilva, and S. Zucoloto, "Immunohistochemical expression of p16, p53, and p63 in colorectal adenomas and adenocarcinomas," Diseases of the Colon and Rectum, vol. 49, no. 5, pp. 588-594, 2006.

[88] S. G. Chi, S. G. Chang, S. J. Lee, C. H. Lee, J. I. Kim, and J. H. Park, "Elevated and biallelic expression of p73 is associated with progression of human bladder cancer," Cancer Research, vol. 59, no. 12, pp. 2791-2793, 1999.

[89] P. Puig, P. Capodieci, M. Drobnjak et al., "p73 Expression in human normal and tumor tissues: loss of $\mathrm{p} 73 \alpha$ expression is associated with tumor progression in bladder cancer," Clinical Cancer Research, vol. 9, no. 15, pp. 5642-5651, 2003.

[90] B. J. Park, S. J. Lee, J. I. Kim et al., "Frequent alteration of p63 expression in human primary bladder carcinomas," Cancer Research, vol. 60, no. 13, pp. 3370-3374, 2000.

[91] F. Koga, S. Kawakami, Y. Fujii et al., "Impaired p63 expression associates with poor prognosis and uroplakin III expression 
in invasive urothelial carcinoma of the bladder," Clinical Cancer Research, vol. 9, no. 15, pp. 5501-5507, 2003.

[92] O. Karni-Schmidt, M. Castillo-Martin, T. HuaiShen et al., "Distinct expression profiles of p63 variants during urothelial development and bladder cancer progression," American Journal of Pathology, vol. 178, no. 3, pp. 1350-1360, 2011.

[93] M. M. Kroiss, A. K. Bosserhoff, T. Vogt et al., "Loss of expression or mutations in the p73 tumour suppressor gene are not involved in the pathogenesis of malignant melanomas," Melanoma Research, vol. 8, no. 6, pp. 504-509, 1998.

[94] M. J. Kang, B. J. Park, D. S. Byun et al., "Loss of imprinting and elevated expression of wild-type p73 in human gastric adenocarcinoma," Clinical Cancer Research, vol. 6, no. 5, pp. 1767-1771, 2000.

[95] A. Tannapfel, S. Schmelzer, M. Benicke et al., "Expression of the p53 homologues p63 and p73 in multiple simultaneous gastric cancer," Journal of Pathology, vol. 195, no. 2, pp. 163170, 2001.

[96] A. E. Vilgelm, S. M. Hong, M. K. Washington et al., "Characterization of $\Delta \mathrm{np} 73$ expression and regulation in gastric and esophageal tumors," Oncogene, vol. 29, no. 43, pp. 5861-5868, 2010.

[97] Y. C. Cai, G. Y. Yang, V. Nie et al., "Molecular alterations of p73 in human esophageal squamous cell carcinomas: loss of heterozygosity occurs frequently; loss of imprinting and elevation of p73 expression may be related to defective p53," Carcinogenesis, vol. 21, no. 4, pp. 683-689, 2000.

[98] N. Masuda, H. Kato, T. Nakajima et al., "Synergistic decline in expressions of p73 and p21 with invasion in esophageal cancers," Cancer Science, vol. 94, no. 7, pp. 612-617, 2003.

[99] J. N. Glickman, A. Yang, A. Shahsafaei, F. McKeon, and R. D. Odze, "Expression of p53-related protein p63 in the gastrointestinal tract and in esophageal metaplastic and neoplastic disorders," Human Pathology, vol. 32, no. 11, pp. 1157-1165, 2001.

[100] H. Geddert, S. Kiel, H. J. Heep, H. E. Gabbert, and M. Sarbia, "The role of p63 and $\Delta \mathrm{Np} 63$ (p40) protein expression and gene amplification in esophageal carcinogenesis," Human Pathology, vol. 34, no. 9, pp. 850-856, 2003.

[101] M. Morita, H. Uramoto, S. Nakata et al., "Expression of DeltaNp63 in squamous cell carcinoma of the esophagus," Anticancer Research, vol. 25, no. 5, pp. 3533-3539, 2005.

[102] Y. Takahashi, T. Noguchi, S. Takeno, Y. Kimura, M. Okubo, and K. Kawahara, "Reduced expression of p63 has prognostic implications for patients with esophageal squamous cell carcinoma," Oncology Reports, vol. 15, no. 2, pp. 323-328, 2006.

[103] L. Y. Cao, Y. Yin, H. Li, Y. Jiang, and H. F. Zhang, "Expression and clinical significance of S100A2 and p63 in esophageal carcinoma," World Journal of Gastroenterology, vol. 15, no. 33, pp. 4183-4188, 2009.

[104] A. K. El-Naggar, S. Lai, G. L. Clayman et al., "P73 gene alterations and expression in primary oral and laryngeal squamous carcinomas," Carcinogenesis, vol. 22, no. 5, pp. 729-735, 2001.

[105] L. Faridoni-Laurens, J. Bosq, F. Janot et al., "P73 expression in basal layers of head and neck squamous epithelium: a role in differentiation and carcinogenesis in concert with p53 and p63?" Oncogene, vol. 20, no. 38, pp. 5302-5312, 2001.

[106] A. Weber, U. Bellmann, F. Bootz, C. Wittekind, and A. Tannapfel, "Expression of p53 and its homologues in primary and recurrent squamous cell carcinomas of the head and neck," International Journal of Cancer, vol. 99, no. 1, pp. 2228, 2002.

[107] Y. K. Chen, S. S. Hsue, and L. M. Lin, "p73 expression for human buccal epithelial dysplasia and squamous cell carcinoma: does it correlate with nodal status of carcinoma and is there a relationship with malignant change of epithelial dysplasia?" Head and Neck, vol. 26, no. 11, pp. 945-952, 2004.

[108] L. Lo Muzio, A. Santarelli, R. Caltabiano et al., "p63 overexpression associates with poor prognosis in head and neck squamous cell carcinoma," Human Pathology, vol. 36, no. 2, pp. 187-194, 2005.

[109] S. S. Liu, K. Y. K. Chan, A. N. Y. Cheung, X. Y. Liao, T. W. Leung, and H. Y. S. Ngan, "Expression of $\Delta \mathrm{Np} 73$ and TAp73 $\alpha$ independently associated with radiosensitivities and prognoses in cervical squamous cell carcinoma," Clinical Cancer Research, vol. 12, no. 13, pp. 3922-3927, 2006.

[110] A. N. Cheung, K.-L. Tsun, K.-M. Ng et al., "P634A4 and TAp73 immunocytochemistry in liquid-based cervical cytology-potential biomarkers for diagnosis and progress prediction of cervical neoplasia," Modern Pathology, vol. 23, no. 4, pp. 559-566, 2010.

[111] T. Y. Wang, B. F. Chen, Y. C. Yang et al., "Histologic and immunophenotypic classification of cervical carcinomas by expression of the p53 homologue p63: a study of 250 cases," Human Pathology, vol. 32, no. 5, pp. 479-486, 2001.

[112] Z. Lin, M. Liu, Z. Li, C. Kim, E. Lee, and I. Kim, “ $\Delta$ Np63 protein expression in uterine cervical and endometrial cancers," Journal of Cancer Research and Clinical Oncology, vol. 132, no. 12, pp. 811-816, 2006.

[113] M. Mai, C. Qian, A. Yokomizo et al., "Loss of imprinting and allele switching of p73 in renal cell carcinoma," Oncogene, vol. 17, no. 13, pp. 1739-1741, 1998.

[114] B. Tuna, M. Unlu, G. Asian, M. Secil, and K. Yorukoglu, "Diagnostic and prognostic impact of p63 immunoreactivity in renal malignancies," Analytical and Quantitative Cytology and Histology, vol. 31, no. 2, pp. 118-122, 2009.

[115] A. Ferru, S. Denis, J. Guilhot et al., "Expression of TAp73 and $\Delta \mathrm{Np} 73$ isoform transcripts in thyroid tumours," European Journal of Surgical Oncology, vol. 32, no. 2, pp. 228-230, 2006.

[116] Y. Ito, H. Uramoto, K. Funa et al., "Delta Np73 expression in thyroid neoplasms originating from follicular cells," Pathology, vol. 38, no. 3, pp. 205-209, 2006.

[117] R. Malaguarnera, A. Mandarino, E. Mazzon et al., “The p53homologue p63 may promote thyroid cancer progression," Endocrine-Related Cancer, vol. 12, no. 4, pp. 953-971, 2005.

[118] Y. Ito, T. Takeda, K. Wakasa, M. Tsujimoto, M. Sakon, and N. Matsuura, "Expression of p73 and p63 proteins in pancreatic adenocarcinoma: p73 overexpression is inversely correlated with biological aggressiveness," International Journal of Molecular Medicine, vol. 8, no. 1, pp. 67-71, 2001.

[119] M. G. House, M. Z. Guo, C. Iacobuzio-Donahue, and J. G. Herman, "Molecular progression of promoter methylation in intraductal papillary mucinous neoplasms (IPMN) of the pancreas," Carcinogenesis, vol. 24, no. 2, pp. 193-198, 2003.

[120] O. Basturk, F. Khanani, F. Sarkar, E. Levi, J. D. Cheng, and N. V. Adsay, "DeltaNp63 expression in pancreas and pancreatic neoplasia," Modern Pathology, vol. 18, no. 9, pp. 1193-1198, 2005.

[121] O. Petrenko, A. Zaika, and U. M. Moll, " $\Delta N p 73$ facilitates cell immortalization and cooperates with oncogenic Ras in cellular transformation in vivo," Molecular and Cellular Biology, vol. 23, no. 16, pp. 5540-5555, 2003.

[122] T. Stiewe, S. Zimmermann, A. Frilling, H. Esche, and B. M. Pützer, "Transactivation-deficient $\delta$ TA-p73 acts as 
an oncogene," Cancer Research, vol. 62, no. 13, pp. 35983602, 2002.

[123] H. Cam, H. Griesmann, M. Beitzinger et al., "p53 family members in myogenic differentiation and rhabdomyosarcoma development," Cancer Cell, vol. 10, no. 4, pp. 281-293, 2006.

[124] I. Casciano, B. Banelli, M. Croce et al., "Role of methylation in the control of $\Delta \mathrm{Np} 73$ expression in neuroblastoma," Cell Death and Differentiation, vol. 9, no. 3, pp. 343-345, 2002.

[125] A. Vilgelm, J. X. Wei, M. B. Piazuelo et al., " $\Delta N p 73 \alpha$ regulates MDR1 expression by inhibiting p53 function," Oncogene, vol. 27, no. 15, pp. 2170-2176, 2008.

[126] H. Uramoto, K. Sugio, T. Oyama et al., "Expression of the p53 family in lung cancer," Anticancer Research, vol. 26, no. 3, pp. 1785-1790, 2006.

[127] M. Müller, T. Schilling, A. E. Sayan et al., "TAp73/ $\Delta$ Np73 influences apoptotic response, chemosensitivity and prognosis in hepatocellular carcinoma," Cell Death and Differentiation, vol. 12, no. 12, pp. 1564-1577, 2005.

[128] M. Wager, J. Guilhot, J. L. Blanc et al., "Prognostic value of increase in transcript levels of Tp73 $\Delta \mathrm{Ex} 2-3$ isoforms in lowgrade glioma patients," British Journal of Cancer, vol. 95, no. 8, pp. 1062-1069, 2006.

[129] M. Meier, M. L. den Boer, J. P. P. Meijerink et al., "Differential expression of p73 isoforms in relation to drug resistance in childhood T-lineage acute lymphoblastic leukaemia," Leukemia, vol. 20, no. 8, pp. 1377-1384, 2006.

[130] N. Concin, G. Hofstetter, A. Berger et al., "Clinical relevance of dominant-negative p73 isoforms for responsiveness to chemotherapy and survival in ovarian cancer: evidence for a crucial p53-p73 cross-talk in vivo," Clinical Cancer Research, vol. 11, no. 23, pp. 8372-8383, 2005.

[131] M. Beitzinger, L. Hofmann, C. Oswald et al., "p73 poses a barrier to malignant transformation by limiting anchorageindependent growth," EMBO Journal, vol. 27, no. 5, pp. 792803, 2008.

[132] P. G. Corn, S. J. Kuerbitz, M. M. van Noesel et al., "Transcriptional silencing of the p73 gene in acute lymphoblastic leukemia and Burkitt's lymphoma is associated with 5' CpG island methylation," Cancer Research, vol. 59, no. 14, pp. 3352-3356, 1999.

[133] L. L. Shen, M. Toyota, Y. Kondo et al., "Aberrant DNA methylation of p57KIP2 identifies a cell-cycle regulatory pathway with prognostic impact in adult acute lymphocytic leukemia," Blood, vol. 101, no. 10, pp. 4131-4136, 2003.

[134] G. Garcia-Manero, J. Daniel, T. L. Smith et al., "DNA methylation of multiple promoter-associated CpG islands in adult acute lymphocytic leukemia," Clinical Cancer Research, vol. 8, no. 7, pp. 2217-2224, 2002.

[135] F. Vikhanskaya, W. H. Toh, I. Dulloo et al., "p73 supports cellular growth through c-Jun-dependent AP-1 transactivation," Nature Cell Biology, vol. 9, no. 6, pp. 698-706, 2007.

[136] M. P. Tschan, T. J. Grob, U. R. Peters et al., "Enhanced p73 expression during differentiation and complex p73 isoforms in myeloid leukemia," Biochemical and Biophysical Research Communications, vol. 277, no. 1, pp. 62-65, 2000.

[137] K. Hagiwara, M. G. McMenamin, K. Miura, and C. C. Harris, "Mutational analysis of the p63/p73L/p51/p40/CUSP/KET gene in human cancer cell lines using intronic primers," Cancer Research, vol. 59, no. 17, pp. 4165-4169, 1999.

[138] M. Sunahara, T. Shishikura, M. Takahashi et al., "Mutational analysis of p51A/TAp63 $\gamma$, a p53 homolog, in non-small cell lung cancer and breast cancer," Oncogene, vol. 18, no. 25, pp. 3761-3765, 1999.
[139] K. Hibi, B. Trink, M. Patturajan et al., "AIS is an oncogene amplified in squamous cell carcinoma," Proceedings of the National Academy of Sciences of the United States of America, vol. 97, no. 10, pp. 5462-5467, 2000.

[140] W. M. Keyes, M. Pecoraro, V. Aranda et al., " $\Delta \mathrm{np} 63 \alpha$ is an oncogene that targets chromatin remodeler Lsh to drive skin stem cell proliferation and tumorigenesis," Cell Stem Cell, vol. 8, no. 2, pp. 164-176, 2011.

[141] A. A. Mills, B. Zheng, X. J. Wang, H. Vogel, D. R. Roop, and A. Bradley, "p63 is a p53 homologue required for limb and epidermal morphogenesis," Nature, vol. 398, no. 6729, pp. 708-713, 1999.

[142] A. Yang, R. Schweitzer, D. Sun et al., "p63 is essential for regenerative proliferation in limb, craniofacial and epithelial development," Nature, vol. 398, no. 6729, pp. 714-718, 1999.

[143] E. R. Flores, S. Sengupta, J. B. Miller et al., "Tumor predisposition in mice mutant for p63 and p73: evidence for broader tumor suppressor functions for the p53 family," Cancer Cell, vol. 7, no. 4, pp. 363-373, 2005.

[144] M. I. Koster, S. Kim, A. A. Mills, F. J. DeMayo, and D. R. Roop, "p63 is the molecular switch for initiation of an epithelial stratification program," Genes and Development, vol. 18, no. 2, pp. 126-131, 2004.

[145] R. A. Romano, K. Ortt, B. Birkaya, K. Smalley, and S. Sinha, "An active role of the $\Delta \mathrm{N}$ isoform of $\mathrm{p} 63$ in regulating basal keratin genes K5 and K14 and directing epidermal cell fate," PLoS ONE, vol. 4, no. 5, Article ID e5623, 2009.

[146] T. Crook, J. M. Nicholls, L. Brooks, J. O’Nions, and M. J. Allday, "High level expression of $\Delta \mathrm{N}$-p63: a mechanism for the inactivation of p53 in undifferentiated nasopharyngeal carcinoma (NPC)?” Oncogene, vol. 19, no. 30, pp. 3439-3444, 2000.

[147] K. Yamaguchi, L. Wu, O. L. Caballero et al., "Frequent gain of the p40/p51/p63 gene locus in primary head and neck squamous cell carcinoma," International Journal of Cancer, vol. 86, no. 5, pp. 684-689, 2000.

[148] E. Compérat, I. Bièche, D. Dargère et al., "p63 gene expression study and early bladder carcinogenesis," Urology, vol. 70, no. 3, pp. 459-462, 2007.

[149] S. Marchini, M. Marabese, E. Marrazzo et al., " $\Delta N p 63$ expression is associated with poor survival in ovarian cancer," Annals of Oncology, vol. 19, no. 3, pp. 501-507, 2008.

[150] C. E. Barbieri, L. J. Tang, K. A. Brown, and J. A. Pietenpol, "Loss of p63 leads to increased cell migration and upregulation of genes involved in invasion and metastasis," Cancer Research, vol. 66, no. 15, pp. 7589-7597, 2006.

[151] M. Adorno, M. Cordenonsi, M. Montagner et al., "A Mutantp53/Smad complex opposes p63 to empower TGF $\beta$-induced metastasis," Cell, vol. 137, no. 1, pp. 87-98, 2009.

[152] A. B. Truong, M. Kretz, T. W. Ridky, R. Kimmel, and P. A. Khavari, "p63 regulates proliferation and differentiation of developmentally mature keratinocytes," Genes and Development, vol. 20, no. 22, pp. 3185-3197, 2006.

[153] C. O. Leong, N. Vidnovic, M. P. DeYoung, D. Sgroi, and L. W. Ellisen, "The p63/p73 network mediates chemosensitivity to cisplatin in a biologically defined subset of primary breast cancers," Journal of Clinical Investigation, vol. 117, no. 5, pp. 1370-1380, 2007.

[154] J. W. Rocco, C. O. Leong, N. Kuperwasser, M. P. DeYoung, and L. W. Ellisen, "p63 mediates survival in squamous cell carcinoma by suppression of p73-dependent apoptosis," Cancer Cell, vol. 9, no. 1, pp. 45-56, 2006. 
[155] X. Guo, W. M. Keyes, C. Papazoglu et al., "TAp63 induces senescence and suppresses tumorigenesis in vivo," Nature Cell Biology, vol. 11, no. 12, pp. 1451-1457, 2009.

[156] S. Djelloul, M. Tarunina, K. Barnouin, A. Mackay, and P. S. Jat, "Differential protein expression, DNA binding and interaction with SV40 large tumour antigen implicate the p63-family of proteins in replicative senescence," Oncogene, vol. 21, no. 7, pp. 981-989, 2002.

[157] D.-Y. Wang, C.-C. Cheng, M.-H. Kao, Y.-J. Hsueh, D. H. K. Ma, and J.-K. Chen, "Regulation of limbal keratinocyte proliferation and differentiation by TAp63 and $\Delta \mathrm{Np} 63$ transcription factors," Investigative Ophthalmology and Visual Science, vol. 46, no. 9, pp. 3102-3108, 2005.

[158] W. Guo, S. Fan, Y. Jiang, J. Chen, Z. Li, and H. Niu, "The expression of p63 gene in human non-small cell lung cancer," Zhongguo Fei Ai Za Zhi, vol. 7, no. 1, pp. 31-34, 2004.

[159] X. Su, D. Chakravarti, M. S. Cho et al., “TAp63 suppresses metastasis through coordinate regulation of Dicer and miRNAs," Nature, vol. 467, no. 7318, pp. 986-990, 2010.

[160] S. Wang and W. S. El-Deiry, "p73 or p53 directly regulates human p53 transcription to maintain cell cycle checkpoints," Cancer Research, vol. 66, no. 14, pp. 6982-6989, 2006.

[161] X. Chen, Y. Zheng, J. Zhu, J. Jiang, and J. Wang, "p73 is transcriptionally regulated by DNA damage, p53, and p73," Oncogene, vol. 20, no. 6, pp. 769-774, 2001.

[162] J. Wang, Y. X. Liu, M. P. Hande, A. C. Wong, Y. J. Jin, and Y. Yin, "TAp73 is a downstream target of p53 in controlling the cellular defense against stress," Journal of Biological Chemistry, vol. 282, no. 40, pp. 29152-29162, 2007.

[163] J. Johnson, J. Lagowski, S. Lawson, Y. Liu, and M. KuleszMartin, "p73 expression modulates p63 and Mdm2 protein presence in complex with p53 family-specific DNA target sequence in squamous cell carcinogenesis," Oncogene, vol. 27, no. 19, pp. 2780-2787, 2008.

[164] S. Strano, G. Fontemaggi, A. Costanzo et al., "Physical interaction with human tumor-derived p53 mutants inhibits p63 activities," Journal of Biological Chemistry, vol. 277, no. 21, pp. 18817-18826, 2002.

[165] C. J. Di Como, C. Gaiddon, and C. Prives, "p73 Function is inhibited by tumor-derived p53 mutants in mammalian cells," Molecular and Cellular Biology, vol. 19, no. 2, pp. 14381449, 1999.

[166] C. Gaiddon, M. Lokshin, J. Ahn, T. Zhang, and C. Prives, "A subset of tumor-derived mutant forms of p53 down-regulate p63 and p73 through a direct interaction with the p53 core domain," Molecular and Cellular Biology, vol. 21, no. 5, pp. 1874-1887, 2001.

[167] C. D. Pozniak, S. Radinovic, A. Yang, F. McKeon, D. R. Kaplan, and F. D. Miller, "An anti-apoptotic role for the p53 family member, p73, during developmental neuron death," Science, vol. 289, no. 5477, pp. 304-306, 2000.

[168] G. Liu, S. Nozell, H. Xiao, and X. Chen, “ $\Delta N p 73 \beta$ is active in transactivation and growth suppression," Molecular and Cellular Biology, vol. 24, no. 2, pp. 487-501, 2004.

[169] E. R. Flores, K. Y. Tsai, D. Crowley et al., "p63 and p73 are required for p53-dependent apoptosis in response to DNA damage," Nature, vol. 416, no. 6880, pp. 560-564, 2002.

[170] R. Cui, T. T. Nguyen, J. H. Taube, S. A. Stratton, M. H. Feuerman, and M. C. Barton, "Family members p53 and p73 act together in chromatin modification and direct repression of $\alpha$-fetoprotein transcription," Journal of Biological Chemistry, vol. 280, no. 47, pp. 39152-39160, 2005.
[171] A. Yang, Z. Zhu, A. Kettenbach et al., "Genome-wide mapping indicates that p73 and p63 Co-occupy target sites and have similar DNA-binding profiles in vivo," PLOS ONE, vol. 5, no. 7, Article ID e11572, 2010. 

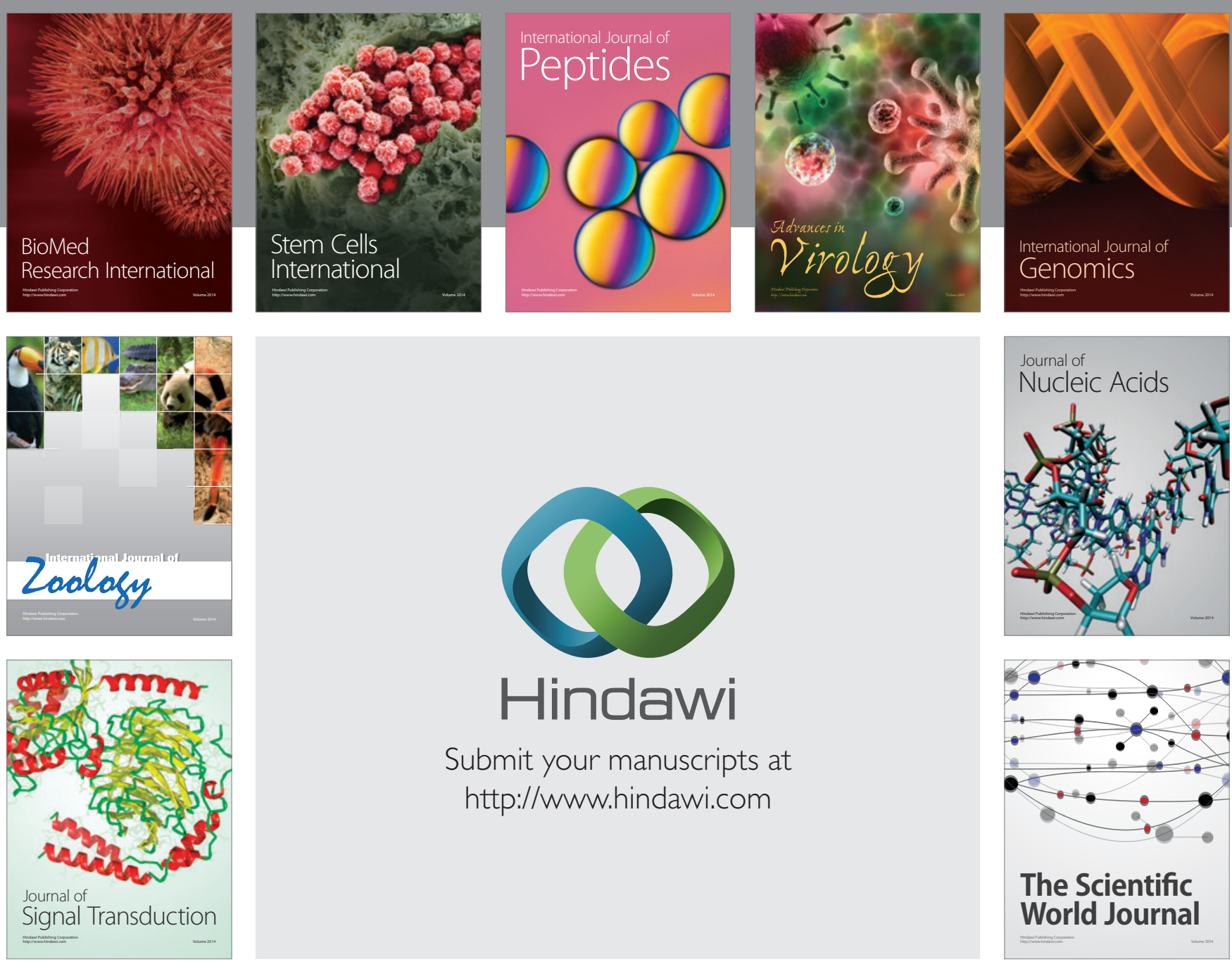

Submit your manuscripts at

http://www.hindawi.com
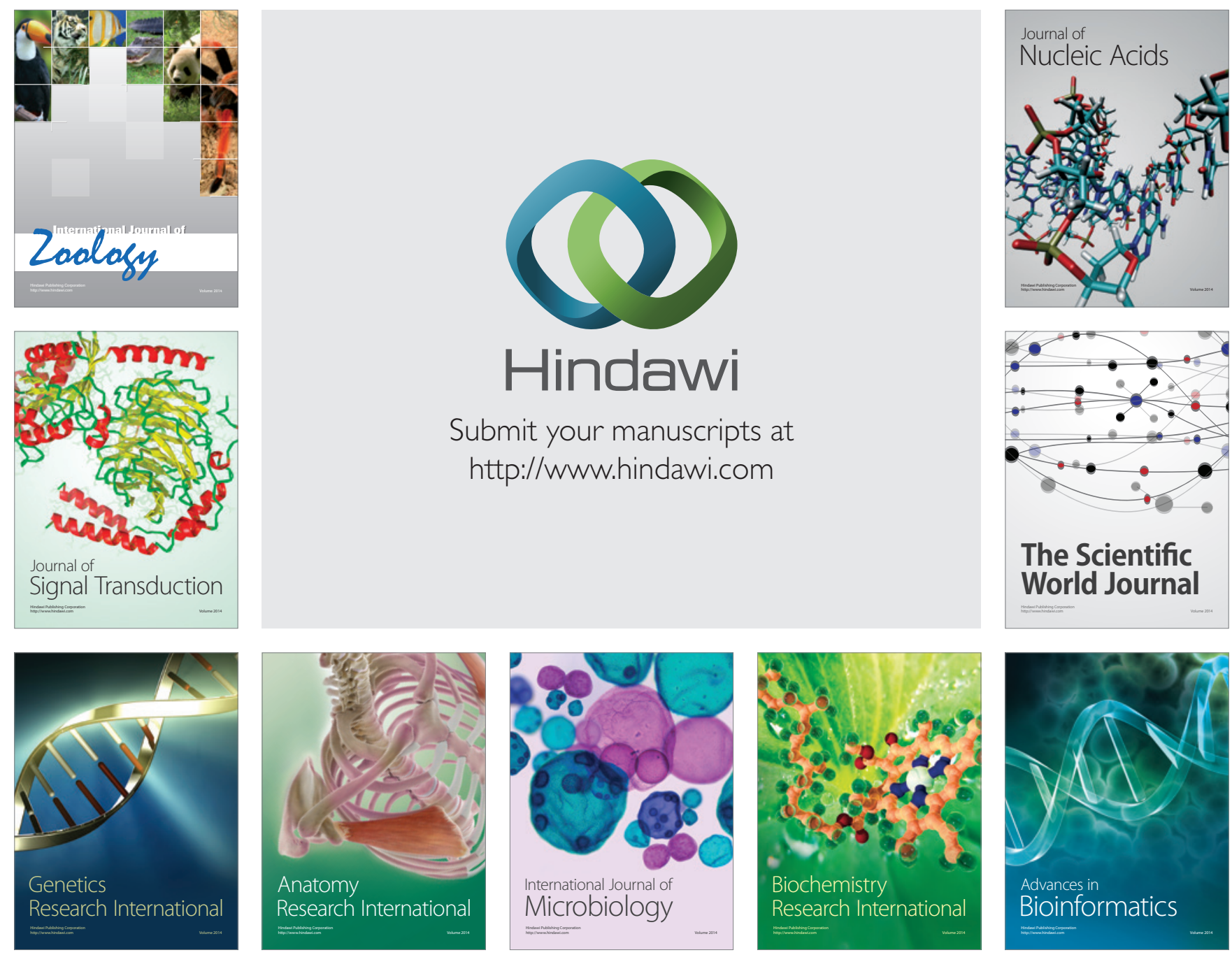

The Scientific World Journal
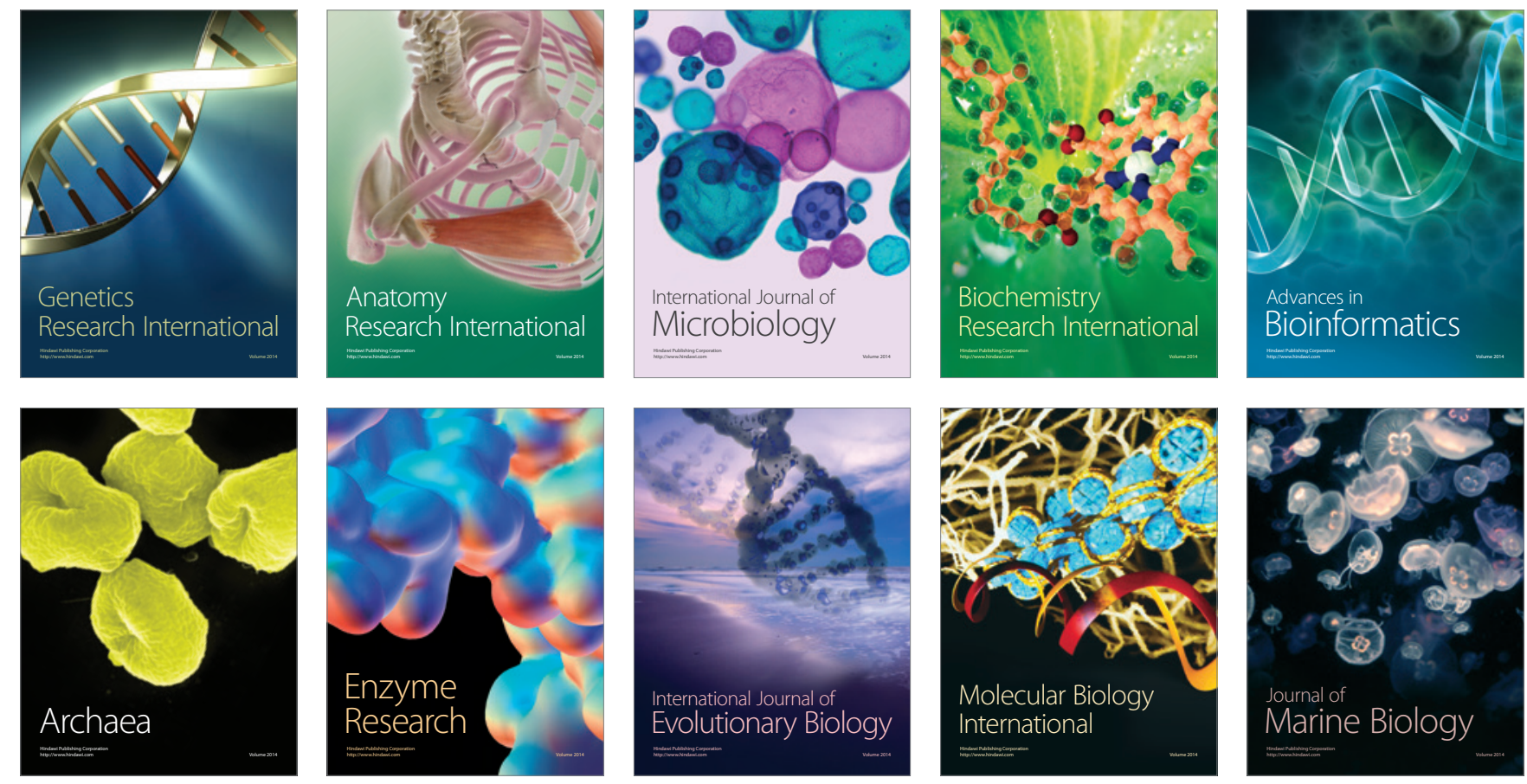